\title{
Effect of Surface Charge and Hydrophobicity Modulation on the Antibacterial and Antibiofilm Potential of Magnetic Iron Nanoparticles
}

\author{
Rania Ibrahim Shebl, ${ }^{1}$ Faten Farouk, ${ }^{1}$ and Hassan Mohamed El-Said Azzazy ${ }^{2}$ \\ ${ }^{1}$ Microbiology and Immunology Department and Pharmaceutical Chemistry Department, Faculty of Pharmacy, \\ Ahram Canadian University, Cairo, Egypt \\ ${ }^{2}$ Department of Chemistry, School of Sciences \& Engineering, American University in Cairo, New Cairo, Egypt
}

Correspondence should be addressed to Hassan Mohamed El-Said Azzazy; hazzazy@aucegypt.edu

Received 18 January 2017; Accepted 24 May 2017; Published 12 September 2017

Academic Editor: Jean M. Greneche

Copyright (c) 2017 Rania Ibrahim Shebl et al. This is an open access article distributed under the Creative Commons Attribution License, which permits unrestricted use, distribution, and reproduction in any medium, provided the original work is properly cited.

\begin{abstract}
Unmodified magnetic nanoparticles (MNPs) lack antibacterial potential. We investigated MNPs surface modifications that can impart antibacterial activity. Six MNPs species were prepared and characterized. Their antibacterial and antibiofilm potentials, surface affinity, and cytotoxicity were evaluated. Prepared MNPs were functionalized with citric acid, amine group, amino-propyl trimethoxy silane (APTMS), arginine, or oleic acid (OA) to give hydrophilic and hydrophobic MNPs with surface charge ranging from -30 to $+30 \mathrm{mV}$. Prepared MNPs were spherical in shape with an average size of $6-15 \mathrm{~nm}$. Hydrophobic (OA-MNPs) and positively charged MNPs (APTMS-MNPs) had significant concentration dependent antibacterial effect. OA-MNPs showed higher inhibitory potential against S. aureus and E. coli (80\%) than APTMS-MNPs (70\%). Both particles exhibited surface affinity to S. aureus and E. coli. Different concentrations of OA-MNPs decreased S. aureus and E. coli biofilm formation by $50-90 \%$, while APTMS-MNPs reduced it by 30-90\%, respectively. Up to $90 \%$ of preformed biofilms of S. aureus and E. coli were destroyed by OAMNPs and APTMS-MNPs. In conclusion, surface positivity and hydrophobicity enhance antibacterial and antibiofilm properties of MNPs.
\end{abstract}

\section{Introduction}

Nanoparticles (NPs) are gaining attention as a new antimicrobial and antibiofilm approach. They may directly exhibit antibacterial effect or be used as antibiotic carriers [1]. Metal oxides NPs can be prepared easily and stand harsh conditions such as high temperature during sterilization. Metal oxide NPs are expected to overcome the organic molecule drawbacks such as pollution, residence in tissues, high cost, toxicity, and low stability. Their mechanism of action includes production of reactive oxygen species which damages cellular structures, alteration of membrane permeability, interruption of energy transduction, alteration of enzymatic activity, and DNA replication [2].

Iron oxide magnetic nanoparticles (MNPs) have several advantages due to their stability, low preparation cost, and biocompatibility, as well as their manipulation by a magnetic field [3]. MNPs types include hematite $\left(\alpha-\mathrm{Fe}_{2} \mathrm{O}_{3}\right)$, magnetite $\left(\mathrm{Fe}_{3} \mathrm{O}_{4}\right)$, wüstite $(\mathrm{FeO})$, and maghemite $\left(\gamma-\mathrm{Fe}_{2} \mathrm{O}_{3}\right)$. The magnetite and maghemite types have proven biocompatibility. Both types are produced by thermal coprecipitation method $[4,5]$. Magnetite $\mathrm{Fe}_{3} \mathrm{O}_{4}$ (black) is produced under anaerobic conditions while maghemite $\gamma-\mathrm{Fe}_{2} \mathrm{O}_{3}$ is the magnetite oxidation product (brown). MNPs range in size from few to hundreds of nanometers [6]. They have many bioapplications, such as magnetic bioseparation and detection of biological entities, diagnostic applications as magnetic resonance imaging, and therapeutic applications as targeted drug delivery and biological labels [7].

MNPs are generally very reactive and tend to aggregate quickly to decrease their surface energy which leads to alteration in their size and magnetic properties. Surface coating of 
TABLE 1: Antibacterial effects of MNPs with different surface groups.

\begin{tabular}{|c|c|c|c|c|c|}
\hline $\begin{array}{l}\text { Iron coating or functional } \\
\text { group }\end{array}$ & $\begin{array}{l}\text { Surface charge } \\
(\mathrm{mV})\end{array}$ & Hydrophobicity/hydrophilicity & Bacterial strain tested & Effect on bacteria & Ref. \\
\hline $\begin{array}{l}\text { Iron functionalized with } \\
\text { Henna Extract "2-hydroxy- } \\
\text { 1,4-naphthoquinone" and } \\
\text { Gardenia Leave Extract }\end{array}$ & - & - & $\begin{array}{c}\text { E. coli, } S . \text { enterica, } P \text {. } \\
\text { mirabilis, and } S . \\
\text { aureus }\end{array}$ & Inhibited growth & {$[34]$} \\
\hline${ }^{*} \mathrm{OA}-\mathrm{MNP}$ & -40 & Hydrophobic & $\begin{array}{l}\text { S. aureus and } P \text {. } \\
\text { aeruginosa }\end{array}$ & $\begin{array}{l}\text { (i) Inhibited growth } \\
\text { (ii) Showed } \\
\text { antibiofilm activity }\end{array}$ & {$[35]$} \\
\hline Glycerol, MNPs & - & Hydrophilic & $\begin{array}{l}\text { P. aeruginosa, } E \text {. } \\
\text { faecalis }\end{array}$ & Stimulated growth & {$[36]$} \\
\hline $\begin{array}{l}\text { Extract of } A . \text { Mexicana, } \\
\text { MNPs } \\
\text { MNPs }\end{array}$ & - & $\begin{array}{l}\text { Hydrophilic } \\
\text { Hydrophilic }\end{array}$ & $\begin{array}{l}\text { E. coli, P. mirabilis, } \\
\text { and B. subtilis }\end{array}$ & $\begin{array}{c}\text { Inhibited growth } \\
\text { No effect }\end{array}$ & {$[37]$} \\
\hline Chitosan-MNPs & 61.8 & Hydrophilic & E. Coli & Inhibited growth & {$[38]$} \\
\hline MNPs & 43.7 & Hydrophilic & & Inhibited growth & \\
\hline CES-MNPs & -15.4 & Hydrophilic & S. aureus and $S$. & Inhibited growth & \\
\hline APTES-MNPs & 32.6 & Hydrophilic & epidermidis & Inhibited growth & [39] \\
\hline PEG-MNPs & -7.7 & Amphiphilic & & No effect & \\
\hline $\begin{array}{l}\text { MNP } \\
\text { Chitosan-MNP }\end{array}$ & $\begin{array}{l}-32.2 \\
+36.2\end{array}$ & $\begin{array}{l}\text { Hydrophilic } \\
\text { Hydrophilic }\end{array}$ & B. subtilis and E. coli & $\begin{array}{c}\text { No effect } \\
\text { Inhibited growth }\end{array}$ & {$[8]$} \\
\hline $\begin{array}{l}\text { Streptomycin-chitosan- } \\
\text { MNPs }\end{array}$ & - & Hydrophilic & S. aureus & $\begin{array}{c}\text { Enhanced } \\
\text { antibacterial activity }\end{array}$ & {$[40]$} \\
\hline Ampicillin-chitosan-MNPs & +14.4 & Hydrophilic & M. tuberculosis & $\begin{array}{c}\text { Enhanced } \\
\text { antibacterial activity }\end{array}$ & {$[41]$} \\
\hline PVA-MNPs & -19 & Amphiphilic & S. aureus & Inhibited growth & {$[42]$} \\
\hline Citric acid-MNPs & -30 & Hydrophilic & M. smegmatis & No effect & {$[43]$} \\
\hline Polyacrylic acid-MNPs & -30 & Hydrophilic & M. smegmatis & No effect & {$[7]$} \\
\hline
\end{tabular}

MNPs modulates their aggregation, stability, and dispersion ability $[4,6]$.

Owing to their unique properties, several attempts were performed to investigate the antibacterial and antibiofilm potentials of MNPs. Previous studies showed that MNPs exhibited insignificant or no antibacterial activity, while some surface modifications were successful to impart antibacterial potential (Table 1). Understanding the effect of surface modification of MNPs will enable the optimum selection of surface coating materials offering the greatest antibacterial activity with the least toxicity.

Many bacterial strains produce slime which serves as a matrix in which bacteria are embedded leading to the formation of bacterial biofilm. Bacterial adhesion is mediated by electrostatic, dipole-dipole, $\mathrm{H}$-bond, hydrophobic, and van der Waals interactions [8]. Biofilms promote antibiotic tolerance by reducing antibiotic entry into the bacterial cells. Bacteria in the biofilm can also grow slowly to adapt to depletion of nutrient and accumulation of waste [9]. Bacterial biofilm can adhere to surfaces or exist in flowing system like water columns [10]. Bacterial infection which forms a biofilm will be transformed from an acute to a chronic infection which is difficult to eradicate. Eradicating bacteria in a biofilm will require either mechanical removal or long time combination of high doses of antibiotics [11]. NPs with antibiofilm ability will greatly reduce the antibiotic use. Antibacterial NPs having ability to reduce bacterial biofilm formation can exert their function by preventing bacterial adhesion to surfaces and increasing the bacterial cell exposure to surrounding environment [9].

The present study aimed to compare the effect of hydrophobicity and surface charge modulation on the antibacterial and antibiofilm potentials of MNPs. MNPs with different surface fictionalizations that result in different surface charge and hydrophobicity were synthesized and compared in terms of antibacterial activity, inhibition of bacterial biofilm formation, destruction of preformed biofilm, and their safety to human cells. Comparison was performed against Grampositive $S$. aureus and Gram-negative E. coli. To the best of our knowledge, this is the first attempt to compare the effect of hydrophobicity and charge modification on MNPs' antibacterial potential and antibiofilm formation ability.

\section{Materials and Methods}

2.1. Material and Instrumentation. $\mathrm{FeCl}_{3}, \mathrm{FeSO}_{4}$, ammonia solution (25\%), citric acid, and oleic acid were obtained from Al-Gomhoreya for Chemical Industries in Cairo, Egypt. Arginine (Arg) and amino-propyl trimethoxy silane (APTMS) 
were obtained from Sigma Aldrich (St. Louis, MO). Deionized (DI) water was produced in house by a Milli-Q system (Milford, Connecticut, USA). Mueller Hinton broth was obtained from Sigma Aldrich. E. coli (ATCC-8739) and S. aureus (ATCC-6538) strains and normal human epithelial (WISH) cells (ATCC-CCL25) were generously provided by VACSERA (Cairo, Egypt). Phosphate buffer saline (PBS) was purchased from Biowhittaker-Belgium. Dynatech Microplate Reader (MR 5000Er, West Sussex, UK) and a Jenway 6850 Spectrometer (Staffordshire, UK) were used.

\subsection{Methods of MNPs Synthesis}

2.2.1. Synthesis of Magnetic Iron Nanoparticles (MNPs). Thermal coprecipitation method was adopted for the preparation of MNPs using $\mathrm{FeCl}_{3}, \mathrm{FeSO}_{4}$, and 35\% ammonia solution (Figure 1). Briefly, $5.5 \mathrm{~g}$ of $\mathrm{FeCl}_{3}$ and $2.75 \mathrm{~g}$ of $\mathrm{FeSO}_{4}$ were weighed and dissolved in DI water $(1 \mathrm{~L})$. The solution was heated at $70^{\circ} \mathrm{C}$ for $30 \mathrm{~min}$ [12]. Five $\mathrm{mL}$ of ammonia solution was added until a black precipitate was formed (Magnetite $\mathrm{Fe}_{3} \mathrm{O}_{4}$ ). The reaction was continued for additional $10 \mathrm{~min}$. Solution was evaporated to dryness in rotavap to remove adsorbed ammonia. Residue was then washed six times with DI water and surface charge was measured until shifted to negative $(-20 \mathrm{mV})$ indicating complete desorption of surface ammonia. The MNPs were then dried in oven at $180^{\circ} \mathrm{C}$ and grinded before use. The powder turned into the brown maghemite $\left(\gamma-\mathrm{Fe}_{2} \mathrm{O}_{3}\right)$ solid (supplementary information 1, in Supplementary Material available online at https://doi.org/10.1155/2017/3528295). Prepared MNPs (200 mg) were weighed and suspended in $100 \mathrm{~mL}$ DI water. The X-ray diffraction (XRD) analysis (supplementary materials 2) and transmission electron microscope (TEM) imaging (Figure 2) of the prepared particles were performed.

2.2.2. Preparation of Oleic Acid (OA) Functionalized MNPs (OA-MNPs). OA-MNPs were synthesized according to the methods of $[13,14]$, with some modifications. Excess oleic acid (OA) was added $(3 \mathrm{~mL})$ to black magnetite particles with stirring for $1 \mathrm{~h}$ at $70^{\circ} \mathrm{C}$. Two layers were formed: the upper OA layer was separated in a separating funnel and washed three times with DI water. MNPs were collected by a magnet and then washed 6 times with ethanol to remove excess OA. OA-MNPs were then tested for removal of uncoated OA by FTIR in terms of absence of $\mathrm{C}=\mathrm{O}$ peak of OA indicating chemosorption of OA on MNPs (Figure 3(a)) $[14,15]$. Chemosorption of OA was further verified by the shift in zeta potential (Figure 3(b)) and the lack of dispersion ability of particles in water (Supplementary material 3a and b). OA-MNPs were air dried to remove excess alcohol grinded and weighed $(200 \mathrm{mg})$. OA-MNPs were then mixed with $40 \mu \mathrm{L}$ of Tween 80 in a glass mortar and DI water was added dropwise for the first $10 \mathrm{~mL}$ and then portionwise until the volume was completed to $100 \mathrm{~mL}$ [13].

2.2.3. Preparation of Amine Coated MNPs (A-MNPs). The black magnetite particles were extracted from their reaction mixture after being left for aging at room temperature for $3 \mathrm{~h}$ with the excess ammonia in closed condition. A-MNPs were washed with acidified DI water and then with cold DI water to remove excess ammonia and other inorganic components. The particles were charge measured and FTIR scanned. AMNPs were then reconstituted in DI water $(2 \mathrm{mg} / \mathrm{mL})$ [16].

2.2.4. Preparation of Citrate Coated MNPs (CA-MNPs). CAMNPs were prepared as described in $[17,18]$ with some modifications. Solution of citric acid was prepared by dissolving $38.4 \mathrm{mg}$ of citric acid in $1 \mathrm{~L}$ of DI water. The solution was heated at $80^{\circ} \mathrm{C}$ (Solution 1). $\mathrm{FeCl}_{3}\left(5.5 \mathrm{~g}\right.$ ) and $\mathrm{FeSO}_{4}(2.75 \mathrm{~g}$ ) were weighed and dissolved in DI water $(1 \mathrm{~L})$. The solution was heated at $70^{\circ} \mathrm{C}$ for $30 \mathrm{~min}$. Five $\mathrm{mL}$ of ammonia solution was added until black precipitate is formed. The reaction was continued for $10 \mathrm{~min}$ (Solution 2). Solution 2 was added on solution 1 dropwise with stirring. The mixture was heated for $20 \mathrm{~min}$ and washed with DI water. The resulting CAMNPs were air dried, grinded, and examined for FTIR and zeta potential change. Finally, a suspension of $2 \mathrm{mg} / \mathrm{mL}$ was prepared for application [17].

2.2.5. Preparation of MNPs Coated with Arginine (Arg-MNPs). Unfunctionalized MNPs (100 mg) were transferred into a glass mortar and $20 \mathrm{mg}$ of arginine (Arg) was added followed by $1 \mathrm{~mL} \mathrm{HCl}$. The mixture was mixed using a pestle and diluted with DI water $(100 \mathrm{~mL})$ and then transferred into a stoppered conical flask for $6 \mathrm{~h}$ reflux. Arg-MNPs were separated using an external magnet and washed with DI water six times. Arg-MNPs were air dried followed by grinding. A $2 \mathrm{mg} / \mathrm{mL}$ solution was prepared [19].

2.2.6. Preparation of Silane Coated MNPs (APTMS-MNPs). Amino-propyl trimethoxy silane (APTMS) was used as a functionalizing agent for MNPs. Two protocols were followed. In the first protocol (cold synthesis method), $200 \mathrm{mg}$ of MNPs was weighed and suspended in $3 \mathrm{~mL}$ of DI water. The suspension was sonicated for $30 \mathrm{~min}$ for hydration and ensuring homogeneity (I). The MNPs suspension was then poured (100 $\mu \mathrm{L}$ portions) on a glass vial containing $800 \mu \mathrm{L}$ of APTMS placed on an ice path. The mixture was left in ice bath for $3 \mathrm{~h}$ and then washed with DI water for 6 successive times. In the second method (hot synthesis method), $200 \mathrm{mg}$ MNPs were suspended in $10 \mathrm{~mL}$ of acetone (I). APTMS $(400 \mu \mathrm{L})$ were mixed with $10 \mathrm{~mL}$ of acetone (II). Solutions I and II were mixed by sonication for $90 \mathrm{~min}$. The contents were then transferred to a glass stoppered conical flask and refluxed for $3 \mathrm{~h}$ followed by washing. From both methods, $2 \mathrm{mg} / \mathrm{mL}$ suspensions of MNPs were prepared in DI water. Zeta potential scanning was used to compare higher potential change induced by APTMS using both methods (supplementary information 4).

\subsection{Antibacterial and Antibiofilm Activity of Synthesized MNPs}

2.3.1. Antibacterial Activity Screening. Antibacterial effect of MNPs was examined against E. coli (ATCC-8739) and S. aureus (ATCC-6538). MNPs were diluted in Mueller Hinton broth to reach a final concentration of $100 \mu \mathrm{g} / \mathrm{mL}$ and 
$\mathrm{NH}_{4} \mathrm{OH}$

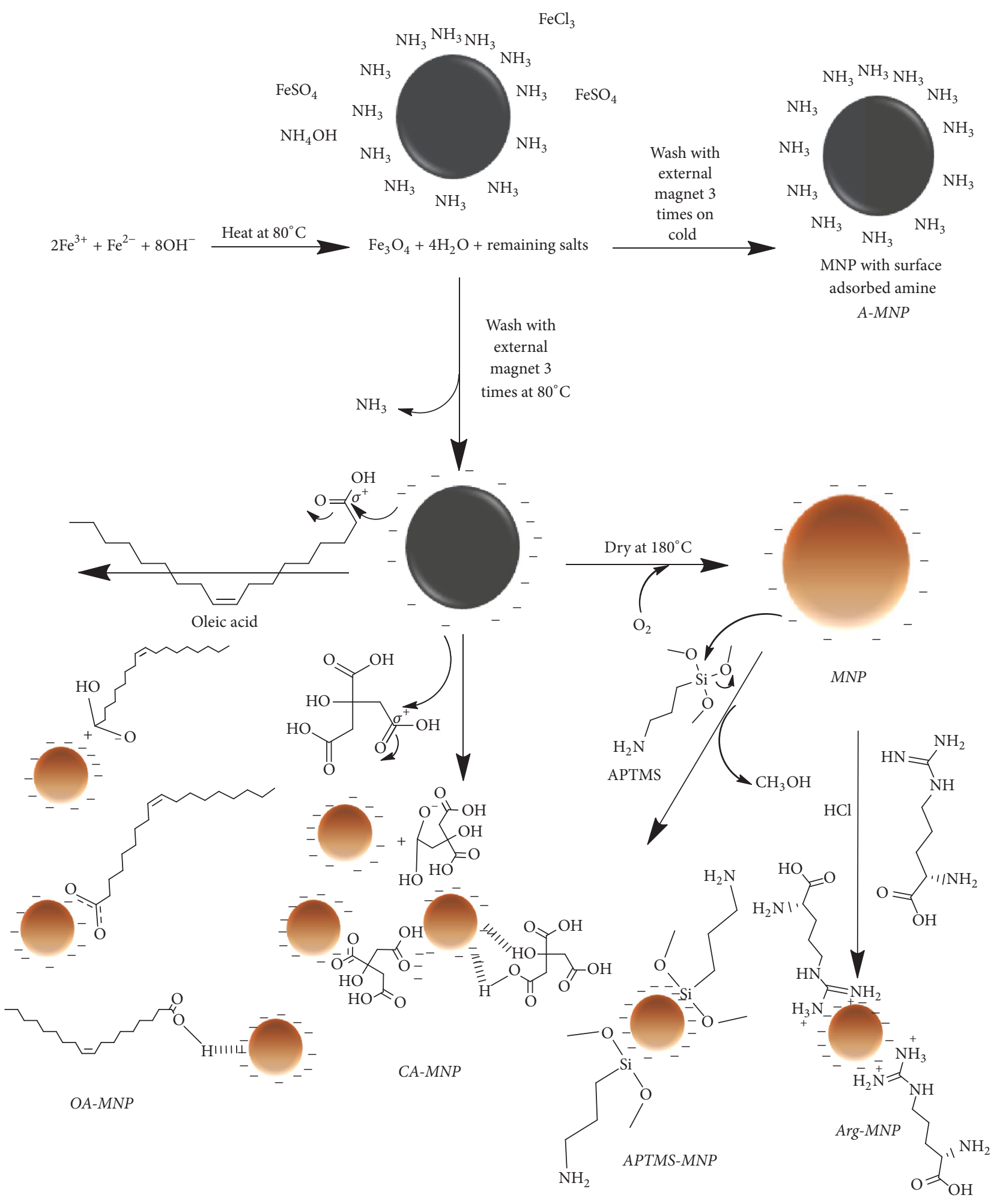

FIGURE 1: Synthesis of magnetic nanoparticles (MNPs). 


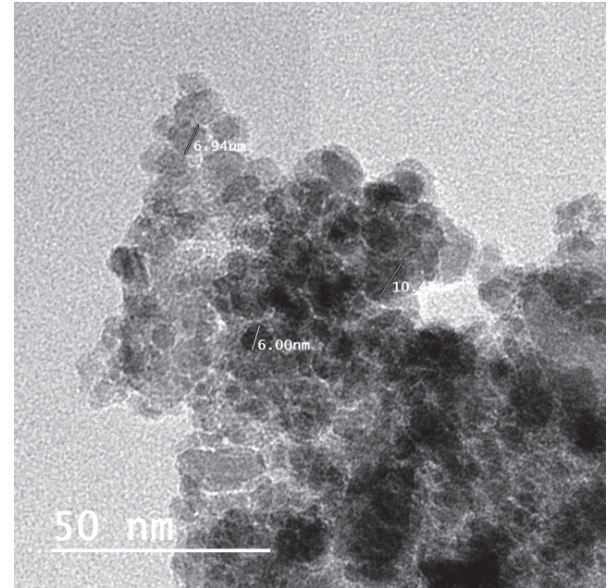

FIGURE 2: TEM image of MNPs prepared by thermal coprecipitation method. Prepared MNPs had an average size of 6-16 $\mathrm{nm}$ and were spherical in shape.

incubated with $18-20 \mathrm{~h}$ subcultured bacterial strains at $37^{\circ} \mathrm{C}$ on a shaker $(200 \mathrm{rpm})$ for $24 \mathrm{~h}$. At the end of the incubation period, samples were obtained from each flask and 10-fold serially diluted in sterile saline. One hundred $\mu \mathrm{L}$ of each dilution as well as control was spread on the surface of 3 nutrient agar plates, incubated at $37^{\circ} \mathrm{C}$ for $24 \mathrm{~h}$, and the average numbers of colony forming units $(\mathrm{CFU} / \mathrm{mL})$ were counted [20]. MNPs species showing promising antibacterial screening were imaged by scanning electron microscope (SEM) to compare their surface morphology.

2.3.2. Effect of Concentration on the Antibacterial Activity of MNPs. The OA-MNPs and APTMS-MNPs were prepared in different dilutions $(25-400 \mu \mathrm{g} / \mathrm{mL})$ and incubated with subcultured bacteria. CFU/mL was counted on surface of agar plates after $24 \mathrm{~h}$ incubation periods.

2.3.3. MNPs Inhibitory Potentials and Growth Kinetics. To evaluate the inhibitory activity of MNPs as well as growth kinetics on tested bacterial strains, culture turbidity was used as a measure of bacterial growth. OA-MNPs and APTMSMNPs were double fold serially diluted in 96-well plate. Positive control wells were double fold serially diluted with DI water. All plates were inoculated with test bacteria as $10 \mu \mathrm{L} /$ well $\left(10^{5} \mathrm{CFU} / \mathrm{mL}\right)$ except for negative control wells (blank); this was carried out to avoid interference caused by light-scattering properties of NP [21]. Plates were incubated at $37^{\circ} \mathrm{C}$ for $24 \mathrm{~h}$ with continuous shaking. Percentage inhibition was calculated according to Sachidananda et al. as follows [22]:

$$
\text { Percentage inhibition }=\left[1-\left(\frac{a}{b}\right) \times 100\right] .
$$

$a$ is optical density of test bacteria with MNPs; $b$ is optical density of positive control wells containing DI water, bacteria, and media.

$\mathrm{MIC}_{50}$ is the lowest MNPs concentration that reduces the bacterial growth by $>50 \%$. Optical density (OD) was measured at 1, 2, 4, 6, and $24 \mathrm{~h}$ intervals using an ELISA plate reader at $600 \mathrm{~nm}$.

2.3.4. Surface Affinity of MNPs to Bacteria. OA-MNPs and APTMS-MNPs were mixed with concentrated bacterial suspension in DI water $(\mathrm{OD}$ of suspension $=1.2)$ to reach a final concentration of $500 \mu \mathrm{g} / \mathrm{mL}$. The suspension was prepared in DI rather than broth to reduce the bacterial growth during the experiment. However, all measurements were performed against suspension control of the same age. The mixture of MNPs and bacteria were allowed to interact together through incubation on a shaker $(200 \mathrm{rpm})$ for a predetermined period of time. MNPs were collected using an external magnet. The bacterial suspension was mixed to resuspend the bacterial cells and samples were collected to measure their OD at $600 \mathrm{~nm}$ using spectrometer. The affinity was calculated from the decrease in OD which occurred upon treating bacterial suspension with MNPs relative to positive control bacteria without MNPs. Optical densities obtained after collecting MNPs alone with a magnet were considered as negative control [23]. The collected MNPs were scanned by FTIR and compared to control MNPs [24].

\subsection{Antibiofilm Activity}

2.4.1. Effect on Biofilm Formation. The effect of MNPs on biofilm formation was carried out by allowing bacterial strains to grow in presence of double fold serially diluted MNPs (OA-MNPs and APTMS-MNPs) in 96 multiwell plates. Plates were incubated at $37^{\circ} \mathrm{C}$ for $24 \mathrm{~h}$. After incubation period, contents of the plates were discarded and plates were washed 3 times with PBS to remove unbound bacteria. Plates were inoculated with $100 \mu \mathrm{L} /$ well crystal violet $(0.15 \%)$ and incubated at room temperature for $30 \mathrm{~min}$. Crystal violet (CV) was discarded; plates were washed again 3 times with phosphate buffer saline (PBS) and allowed to air dry completely. Biofilm formed in each well was resuspended in $97 \%$ ethanol $(200 \mu \mathrm{L} /$ well $)$ and incubated at room temperature for $10 \mathrm{~min}$. The solubilized biomass $(150 \mu \mathrm{L})$ was transferred to sterile 96 well plates to be measured spectrophotometrically at $590 \mathrm{~nm}$. Data were presented as percentage inhibition in biofilm growth in presence as well as in absence of MNPs [25].

2.4.2. Effect on Preformed Biofilm. In 96 multiwell plates, $100 \mu \mathrm{L}$ bacterial suspension $\left(10^{5} \mathrm{CFU} / \mathrm{mL}\right)$ was inoculated in each well and incubated at $37^{\circ} \mathrm{C}$ for $24 \mathrm{~h}$ to initiate biofilm formation. After incubation period, plates were washed 3 times with sterile PBS to remove any unattached cells. Double fold serially diluted MNPs (OA-MNPs and APTMS-MNPs) were added in all wells except in negative control wells and incubated at $37^{\circ} \mathrm{C}$ for $24 \mathrm{~h}$ to evaluate the effect of MNPs on preformed biofilms. MNPs were discarded and the remaining biofilms were stained with CV as previously described [26].

2.5. Cytotoxicity Assay. Ninety-six well-plates were inoculated with normal human epithelial (WISH) cells (ATCCCCL25) at $10^{4}$ cells/well. On confluency, culture media were discarded and plates were inoculated with double fold serially 


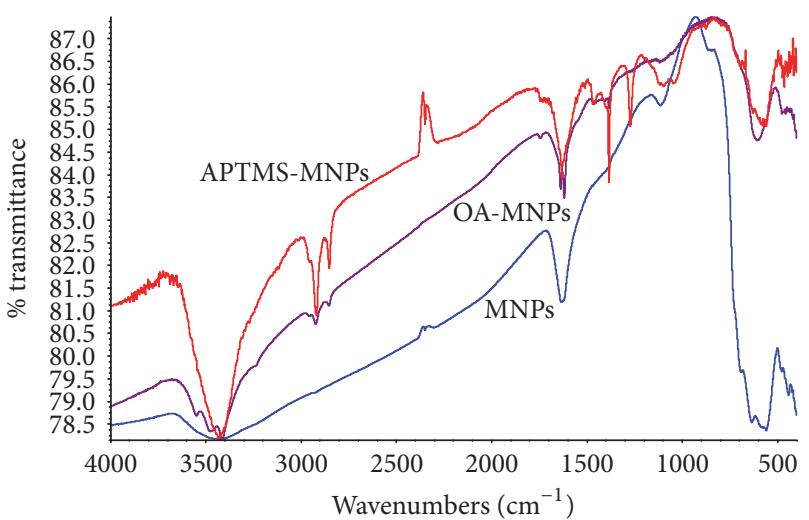

(a)

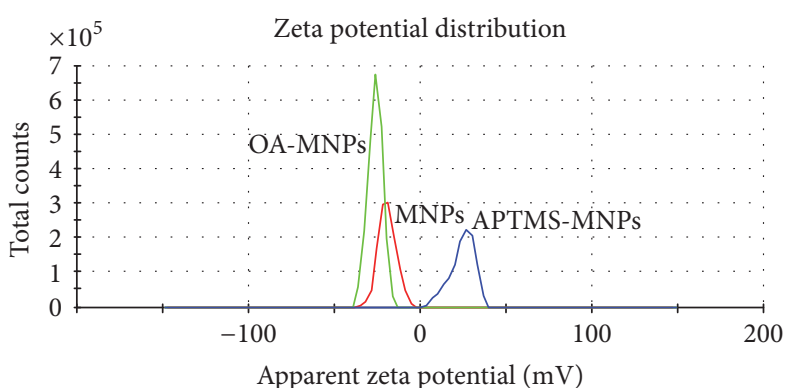

(b)
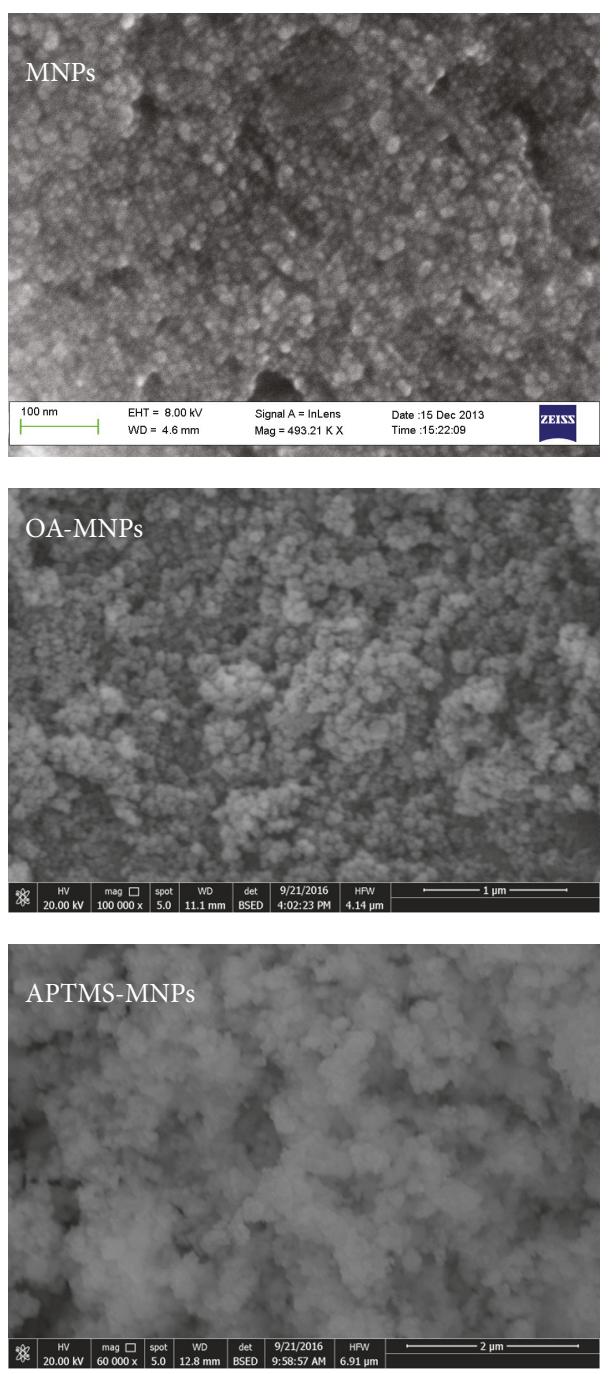

(c)

Figure 3: (a) FT-IR spectra of APTMS-MNP, OA-MNP, and MNPs. MNPs (10 mg) were mixed and grinded with KBr to give a final weight of $0.12 \mathrm{~g}$. The mixture was then pressed into a disc for analysis. Samples were FTIR scanned in the range from 400 to $4000 \mathrm{~cm}^{-1}$ at a resolution of $4 \mathrm{~cm}^{-1}$. Each spectrum is an average of 32 scans. Data is presented as $\%$ transmittance. (b) Surface charge of APTMS-MNP, OA-MNP, and MNP. (c) Scanning electron micrograph of MNP, OA-MNP, and APTMS-MNP. 
diluted MNPs (except negative control wells) and incubated at $37^{\circ} \mathrm{C}$ for $24 \mathrm{~h}$. Residual living cells were treated with $20 \mu \mathrm{L}$ sterile 3-(4,5-dimethylthiazol-2-yl)-2,5-diphenyltetrazolium bromide (MTT) dye $(5 \mathrm{mg} / \mathrm{mL})$ at $37^{\circ} \mathrm{C}$ for $4 \mathrm{~h}$. MTT was discarded and plates were washed with PBS three times. Aliquots of $50 \mu \mathrm{L}$ DMSO were added to each well. Plates were left on plate shaker for $30 \mathrm{~min}$ to allow dissolution of the intracellular formed blue formazan complex. OD was measured at $570 \mathrm{~nm}$ using an ELISA plate reader [27]. Viability percentage was calculated as follows [27]:

Cell viability percentage

$$
=\left(\frac{\text { OD of treated cells }}{\text { OD of untreated cells }}\right) \times 100 \text {. }
$$

\section{Results and Discussion}

\subsection{Results}

3.1.1. Synthesis and Characterization of MNPs. MNPs were prepared using thermal coprecipitation method [12, 28]. Results of XRD analysis shown in supplementary materials (2) are in agreement with the typical pattern for $\gamma-\mathrm{Fe}_{2} \mathrm{O}_{3}$ as initially predicted from the change of their color from black to brown $[29,30]$. Transmission electron microscope imaging revealed that the size of MNP was 6-15 $\mathrm{nm}$ and that they were spherical in shape (Figure 2). Functionalization of the MNPs was performed to prepare hydrophobic MNPs and charge modulated ones (ranging approximately from $-30 \mathrm{mV}$ to $+30 \mathrm{mV}$ ).

Six types of MNP were prepared (Figure 1). Three positive charge shifted MNPs (A-MNPs, Arg-MNPs, and APTMSMNPs) and three negatively charged particles (MNPs, OAMNPs, and CA-MNPs) were prepared and their surface charge was measured (Table 2). Figure 3 compares the FTIR spectrum (a), the surface charge (b), and the scanning electron micrograph of particles (c).

\subsubsection{Antibacterial and Antibiofilm Potential of MNPs}

\section{(1) Antibacterial Activity}

(a) Antibacterial Activity Screening. Synthesized MNPs $(100 \mu \mathrm{g} / \mathrm{mL})$ with different surface charge and functional groups were examined for their antibacterial activities by counting the number of bacterial colonies developed over the surface of agar plates. The highest antibacterial effect was observed for OA-MNPs and APTMS-MNPs. Hydrophobic negatively charged OA-MNPs showed greater reduction in the number of $\mathrm{CFU} / \mathrm{mL}(61 \%, 54 \%)$ compared to that obtained posttreatment with hydrophilic positively charged APTMS-MNPs $(43 \%, 35 \%)$ for S. aureus and E. coli, respectively (Figure 4).

Investigation of the APTMS-MNPs and OA-MNPs antibacterial potential using different concentrations (25-400 $\mu \mathrm{g} / \mathrm{mL}$ ) revealed a concentration dependent reduction in the CFU $24 \mathrm{~h}$ posttreatment (supplementary information 5). At
TABLE 2: Average zeta potential of prepared MNPs $(n=3)$.

\begin{tabular}{lc}
\hline Type of particles & Zeta potential $(\mathrm{mV})$ \\
\hline MNPs & $-18 \pm 3$ \\
CA-MNPs & $-31 \pm 4$ \\
OA-MNPs & $-29 \pm 4$ \\
Arg-MNPs & $-6 \pm 2$ \\
A-MNPs & $-9 \pm 3$ \\
ATPMS-MNPs & $24 \pm 5$ \\
\hline
\end{tabular}

Note. CA-MNP: citric acid modified MNP; OA-MNP: oleic acid modified MNP; Arg-MNP: arginine modified MNP; A-MNP: amine modified MNP; APTMS-MNP: amino-propyl trimethoxy silane MNP.

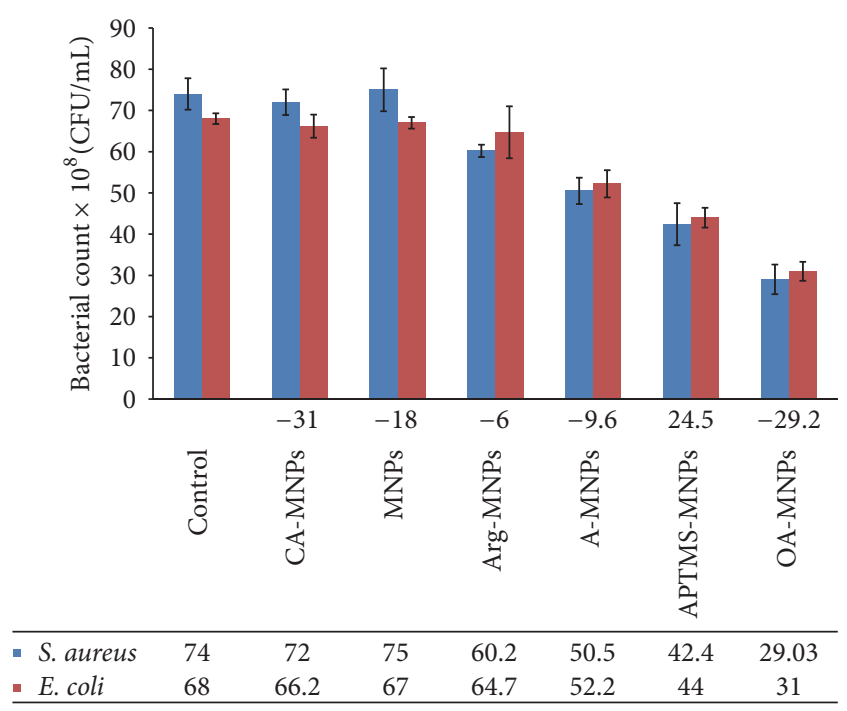

FIgURE 4: Inhibitory potential of MNPs (MNPS, OA-MNPS, CAMNPs, Arg-MNPs, A-MNPs, and APTMS-MNPs) prepared as $100 \mu \mathrm{g} / \mathrm{mL}$ on S. aureus and E. coli after $24 \mathrm{~h}$ treatment based on CFU assay method. Bar chart represents the mean bacterial count $\times 10^{8}$ after treatment by each MNP species (charge displayed in $\mathrm{mV}$ ) as compared to control.

a concentration of $400 \mu \mathrm{g} / \mathrm{mL}$, the OA-MNPs showed inhibition of $83 \%$ and $79 \%$, while the hydrophilic MNPs showed inhibition of $73 \%$ and $72 \%$ for S. aureus and E. coli, respectively (Figures 5(a) and 5(b)).

(b) Effect of MNPs on Bacterial Growth. Inhibitory activity of MNPs was determined using microdilution method by calculating $\mathrm{MIC}_{50}$ after $24 \mathrm{~h}$ treatment. Treating S. aureus and E. coli with OA-MNPs resulted in an $\mathrm{MIC}_{50}$ value of 31 and $63 \mu \mathrm{g} / \mathrm{mL}$, respectively. On the other hand, greater concentration of APTMS-MNPs $(125 \mu \mathrm{g} / \mathrm{mL})$ showed $50 \%$ inhibition towards both bacterial starins (Table 3 ). MIC $_{50}$ results indicated that OA-MNPs and APTMS-MNPs exhibited a greater inhibitory potential on $S$. aureus than that on E. coli (Table 3).

Analysis of growth kinetics reflects a significant time and concentration dependent decrease in OD after OAMNPs and APTMS-MNPs treatment and revealed the growth inhibitory potentials of these particles on test bacteria (Figure 6). 
TABLE 3: Assessment of 50\% minimum inhibitory concentrations $\left(\mathrm{MIC}_{50}\right.$ ) of MNPs using microdilution method.

\begin{tabular}{|c|c|c|c|c|}
\hline \multirow{3}{*}{ MNPs $(\mu \mathrm{g} / \mathrm{mL})$} & \multicolumn{4}{|c|}{$\%$ inhibition } \\
\hline & \multicolumn{2}{|c|}{ S. aureus } & \multicolumn{2}{|c|}{ E. coli } \\
\hline & OA-MNPs & APTMS-MNPs & OA-MNPs & APTMS-MNPs \\
\hline 15.625 & $46 \pm 2$ & $13 \pm 1$ & $31 \pm 1$ & $9 \pm 1$ \\
\hline 31.25 & $58 \pm 2$ & $22 \pm 2$ & $47 \pm 2$ & $20.0 \pm 2$ \\
\hline 62.5 & $62 \pm 2$ & $37 \pm 1$ & $57 \pm 2$ & $34.0 \pm 1$ \\
\hline 125 & $65 \pm 2$ & $54 \pm 4$ & $62 \pm 2$ & $51 \pm 3$ \\
\hline 250 & $68 \pm 3$ & $58 \pm 2$ & $68 \pm 2$ & $60 \pm 1$ \\
\hline 500 & $80 \pm 4$ & $64 \pm 1$ & $71 \pm 3$ & $68 \pm 2$ \\
\hline
\end{tabular}

Note. OA-MNP: oleic acid modified MNP and APTMS-MNP: amino-propyl trimethoxy silane MNP.

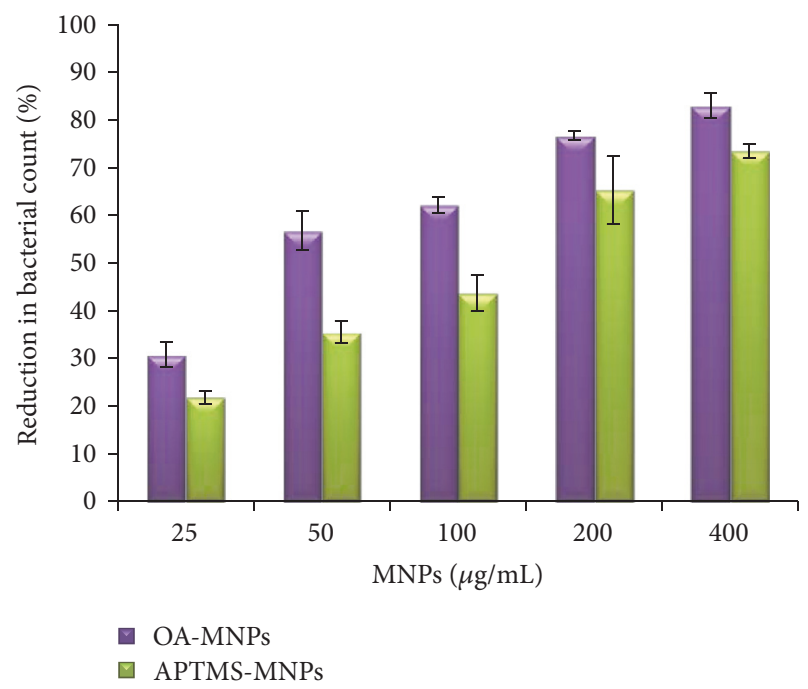

(a)

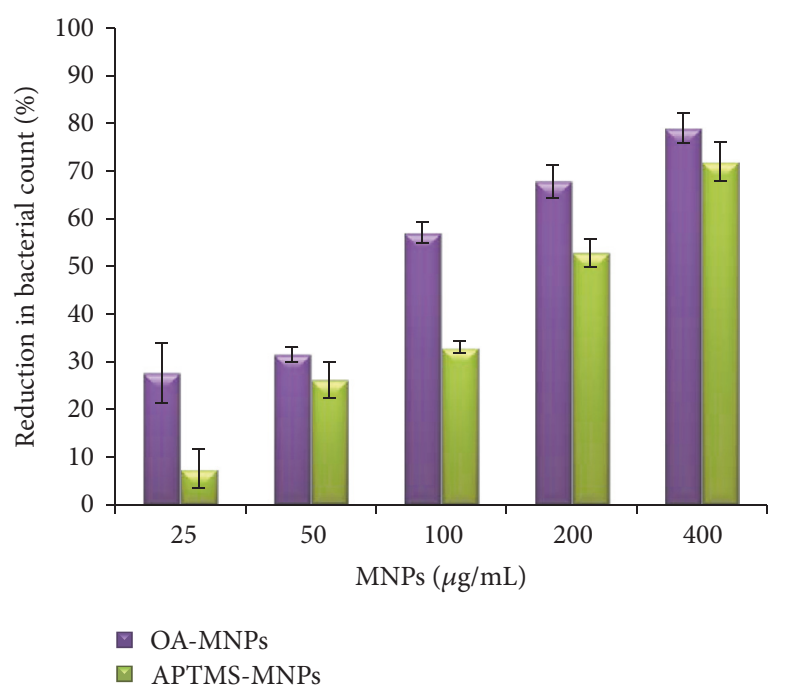

(b)

FIGURE 5: Quantification of bacterial cell number posttreatment with different concentrations of OA-MNPs and APTMS-MNPs in case of $S$. aureus (a) and E. coli (b), respectively. Data revealed a concentration dependent reduction in bacterial count. Values were expressed as mean percentage reduction in bacterial count \pm standard deviation of three independent experiments.

(c) Surface Affinity of MNPs to Bacteria. After bacteria were allowed to interact with MNPs, MNPs were collected using an external magnet at varying time intervals (3-240 $\mathrm{min}$ ). The reduction in OD as compared to initial OD of treated bacterial suspension represents the bacterial cells bound to MNPs.

MNPs bound to bacteria instantly (after $3 \mathrm{~min}$ ). The period of interaction did not affect the binding capacity. OA-MNPs showed the highest percentage reduction ranging between $15 \%-46 \%$ and $30 \%-83 \%$ for S. aureus and E. coli, respectively. Positively charged hydrophilic APTMS-MNPs recorded a lower reduction percentage between $14 \%-32 \%$ and $12 \%-23 \%$ for S. aureus and E. coli, respectively (Figure 7).

The FTIR spectral difference between OA-MNPs before and after attracting bacteria is shown (supplementary information 6). Arrows indicate the position of the characteristic peaks for E. coli and S. aureus, where (a) indicates polysaccharide $\left(900-1200 \mathrm{~cm}^{-1}\right)$ and (b) indicates the band attributed to primary amine $\left(1640-1560 \mathrm{~cm}^{-1}\right)$ [31] for E. coli. For S. aureus, the peaks denoted by (c) and (d) may represent the $\mathrm{C}=\mathrm{N}$ and the $\mathrm{C}-\mathrm{H}$, respectively $[32,33]$.
(2) Effect on Biofilm Formation and Preformed Biofilm. Table 4 and Figure 8 display the percentage reduction in absorbance of stained biofilm by $\mathrm{CV}$ assay after treatment of $S$. aureus and E. coli with different concentrations of OA-MNPs and APTMS-MNPs.

OA-MNPs $(15.6-2000 \mu \mathrm{g} / \mathrm{mL})$ reduced biofilm formation by $62-94 \%$ and $48-96 \%$ for $S$. aureus and E. coli, respectively. APTMS-MNP showed $30-91 \%$ and $34-74 \%$ reduction of the ability of $S$. aureus and E. coli to form a bacterial biofilm, respectively.

OA-MNPs $(15.6-2000 \mu \mathrm{g} / \mathrm{mL})$ destroyed the preformed biofilm by $29-94 \%$ for $S$. aureus and $17-93 \%$ for $E$. coli. APTMS-MNPs $(15.6-2000 \mu \mathrm{g} / \mathrm{mL})$ were able to destroy the preformed biofilm by $19-89 \%$ and $9-77 \%$ for S. aureus and $E$. coli, respectively.

The inhibitory potential of OA-MNPs and APTMSMNPs on the bacterial biofilm during its development increased by increasing the concentration of MNPs. OAMNPs and APTMS-MNPs were able to destroy the preformed biofilm. A higher inhibitory biofilm potential was observed for OA-MNPs over APTMS-MNPs (Table 4). 


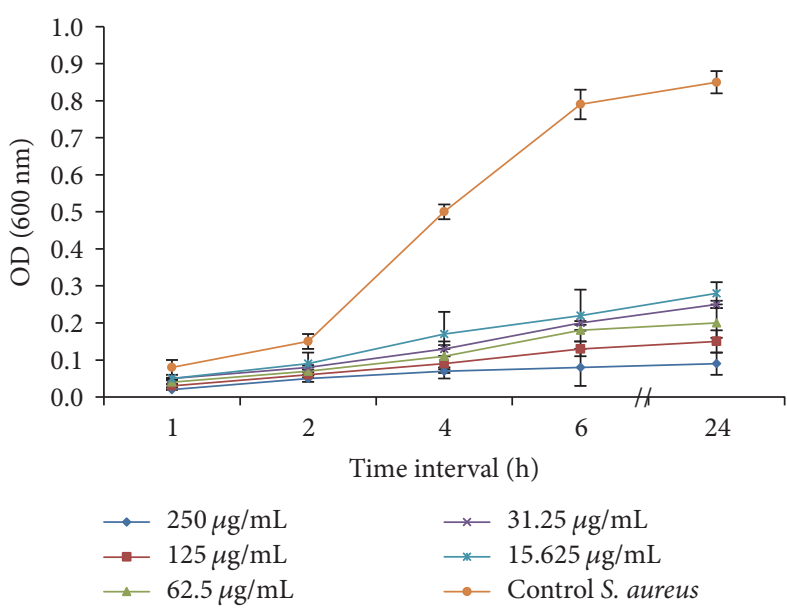

(a)

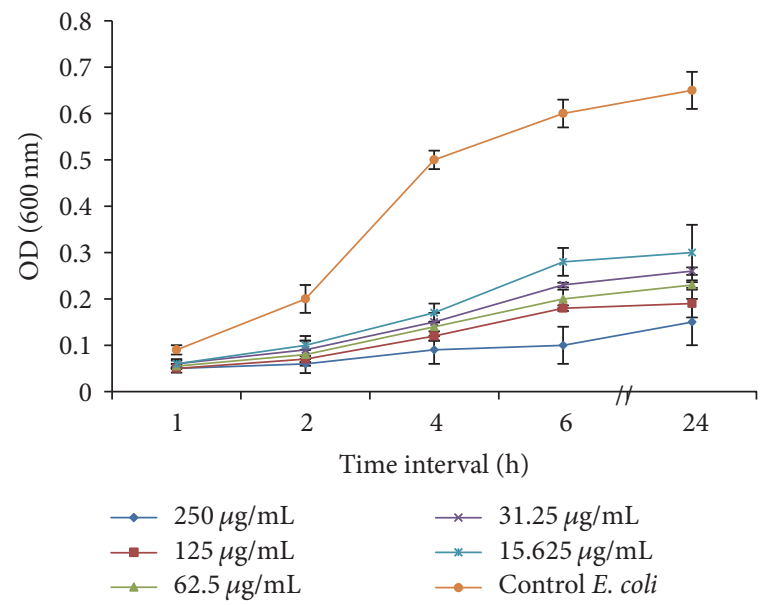

(c)

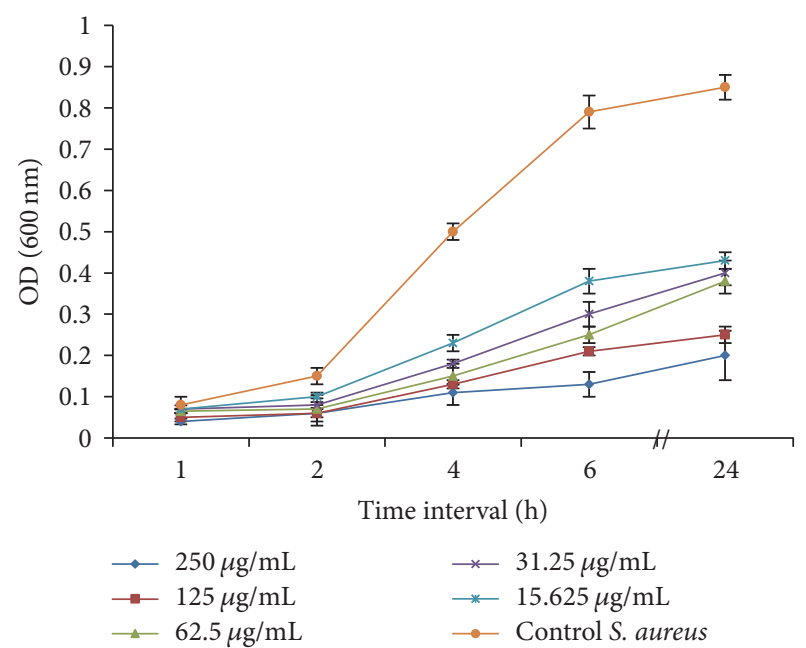

(b)

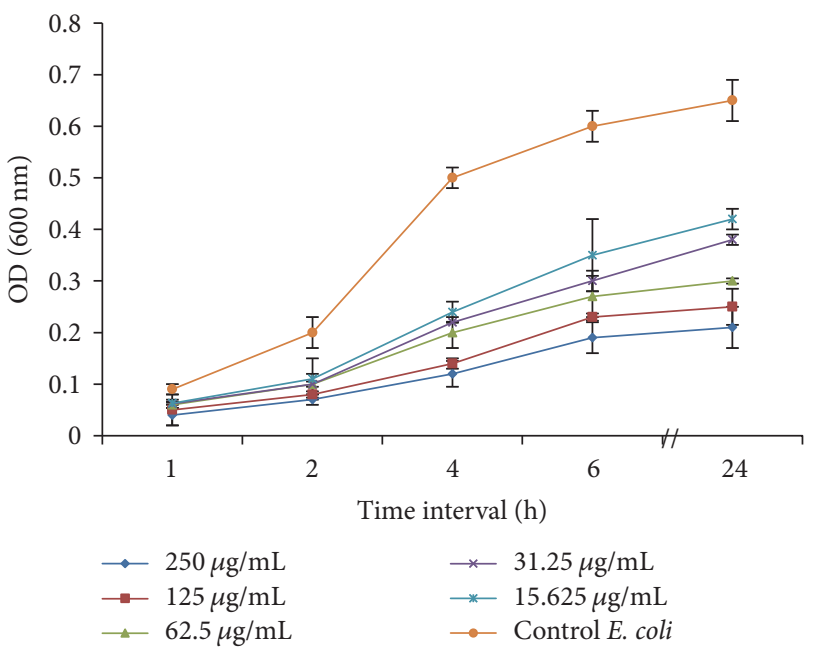

(d)

Figure 6: Growth kinetics of S. aureus ( $\mathrm{a}$ and b) and E. coli ( $\mathrm{c}$ and d) in absence and presence of different concentrations of OA-MNPs (a and c) and APTMS-MNPs (b and d). Bacterial cells were exposed to different concentrations of the MNPs $(15.625,31.25,62.5,125$, and 250 $\mu \mathrm{g} / \mathrm{mL}$ ) at different time intervals compared to untreated control cells. Independent triplicate experiments were carried out for each reaction; error bar represents the standard deviation of mean.

3.1.3. Cytotoxicity Assay. The degree of cytotoxicity of MNPs to normal human (WISH) cells was carried out using MTT assay (Table 5). APTMS-MNPs had no cytotoxic effect up to $250 \mu \mathrm{g} / \mathrm{mL}$. The viability decreased to $85.2 \%$ at a concentration of $500 \mu \mathrm{g} / \mathrm{mL}$. Cell viability deceased from $100 \%$ to $52 \%$ upon treatment with OA-MNPs concentrations between 62.5 and $1000 \mu \mathrm{g} / \mathrm{mL}$, respectively (Figure 9).

3.2. Discussion. There is a need to reduce the use of conventional antibiotics and find alternatives to combat bacterial infections and biofilms. The ability of bacteria to form a biofilm reduces its vulnerability to antibiotics and complicates eradication efforts. In this study, we have investigated the influence of surface functionalization on the antibacterial and antibiofilm properties of MNPs.

MNPs were synthesized by the classical thermal coprecipitation method using ammonia as the alkylating agent.
The prepared MNPs were spherical and of average size of 6-16 $\mathrm{nm}$. The charge of the synthesized MNPs was $-18 \mathrm{mV}$ $[8,31]$. The XRD analysis (supplementary materials 2 ) showed typical pattern for maghemite $\left(\gamma-\mathrm{Fe}_{2} \mathrm{O}_{3}\right)$.

Surface functionalization of MNPs with citric acid was successful to shift surface charge into a more negative potential $(-31 \mathrm{mV})$ [17]. Functionalizing MNPs with OA resulted in an increase in negative potential to $-29.2 \mathrm{mV}[35,44]$. To synthesize positive charge shifted MNPs, Arg (amino acid) induced a charge shift from -18 to $-6 \mathrm{mV}$ [45-47]. Ammonia adsorbed on MNPs' surface was able to shift surface charge to $-9.6 \mathrm{mV}$, while APTMS shifted surface charge of MNPs from -18 to $24.5 \mathrm{mV}$ [23]. Hydrophobicity was induced on MNPs by surface functionalization with OA.

The functionalization of the synthesized MNPs was confirmed by FTIR scanning. The unfunctionalized MNPs showed Fe-O characteristic absorption band at 634.4 and 
TABLE 4: (a) Effect (\% reduction) of OA-MNP and ATMPS-MNP on preformed biofilm for S. aureus and E. coli. (b) Effect (\% reduction) of OA-MNP and ATMPS-MNP on biofilm formation for S. aureus and E. coli.

(a)

\begin{tabular}{lcccc}
\hline MNPs $(\mu \mathrm{g} / \mathrm{mL})$ & OA-MNPs/S. aureus & APTMS-MNPs/S. aureus & OA-MNPs/E. coli & APTMS-MNPs/E. coli \\
\hline 15.625 & 29 & 19 & 17 & 9 \\
31.25 & 53 & 24 & 33 & 15 \\
62.5 & 70 & 41 & 45 & 39 \\
125 & 76 & 52 & 55 & 45 \\
250 & 79 & 60 & 62 & 58 \\
500 & 80 & 72 & 70 & 64 \\
1000 & 86 & 74 & 79 & 72 \\
2000 & 94 & 89 & 93 & 77 \\
\hline
\end{tabular}

(b)

\begin{tabular}{lcccc}
\hline MNPs $(\mu \mathrm{g} / \mathrm{mL})$ & OA-MNPs/S. aureus & APTMS-MNPs/S. aureus & OA-MNPs/E. coli & APTMS-MNPs/E. coli \\
\hline 15.625 & 62 & 30 & 48 & 34 \\
31.25 & 67 & 33 & 64 & 35 \\
62.5 & 86 & 43 & 67 & 38 \\
125 & 86 & 50 & 81 & 39 \\
250 & 90 & 74 & 87 & 44 \\
500 & 92 & 79 & 92 & 51 \\
1000 & 93 & 86 & 93 & 69 \\
2000 & 94 & 91 & 96 & 74 \\
\hline
\end{tabular}

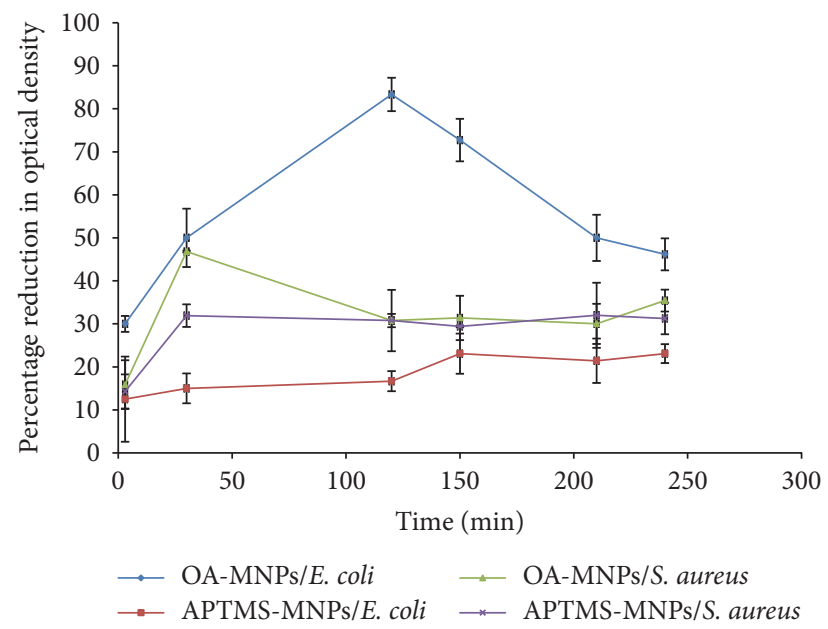

FIgURE 7: Surface affinity of MNPs to S. aureus and E. coli postexposure at different time intervals. MNPs were collected with external magnet and optical density of the remaining solution was measured spectrophotometrically. Data was recorded as percentage reduction in optical density at time interval of three independent tests.

$557.5 \mathrm{~cm}^{-1}$ [48]. Two other bands around $3422.7 \mathrm{~cm}^{-1}$ and $1634.9 \mathrm{~cm}^{-1}$ correspond to stretching and bending vibrations of surface hydroxyl groups on surface of MNPs [49]. OAMNPs showed OA coating characteristic bands at 2923.8 and $2852.9 \mathrm{~cm}^{-1}$ which correspond to $\mathrm{CH}_{3}$ stretching. The $\mathrm{C}=\mathrm{O}$ appeared as a peak at $1638 \mathrm{~cm}^{-1}$ and at $1618.3 \mathrm{~cm}^{-1}$ which supports the formation of a chelating bidentate interaction
TABLE 5: Cytotoxicity of APTMS-MNPs and OA-MNPs against WISH cells.

\begin{tabular}{lcc}
\hline MNPs $(\mu \mathrm{g} / \mathrm{mL})$ & \multicolumn{2}{c}{ Average \% cell viability } \\
APTMS-MNPs
\end{tabular}

between the $\mathrm{COO}^{-}$and the MNPs which resulted in the blue shift of the original $\mathrm{C}=\mathrm{O}$ peak of $\mathrm{OA}$ which appears at $1731 \mathrm{~cm}^{-1}$. Harris et al. also reported the $\mathrm{COO}^{-}$of OA to appear as a broad band between 1541 and $1639 \mathrm{~cm}^{-1}$ and concluded that the bonding pattern of the carboxylic acids on the surface of the NP was at an angle to the surface [50].

A-MNPs showed an amine peak between 3410 and $3457 \mathrm{~cm}^{-1}$. CA-MNPs showed a peak at $2958.5 \mathrm{~cm}^{-1}$ which corresponds to $\mathrm{CH}_{2}$ stretching. The $\mathrm{C}=\mathrm{O}$ of citric acid appeared at $1638 \mathrm{~cm}^{-1}$ [51]. Arg-MNPs showed amine peak between 3410 and $3450 \mathrm{~cm}^{-1}$, a C=O peak at $1634.9 \mathrm{~cm}^{-1}$, and a $\mathrm{CH}_{2}$ stretching band at $2923.2 \mathrm{~cm}^{-1}$ [52]. APTMS-MNPs were characterized by the $\mathrm{CH}_{2}$ stretching which appeared at 2920.8 and $2851.3 \mathrm{~cm}^{-1}, \mathrm{~N}-\mathrm{H}$ bending appeared at $1631 \mathrm{~cm}^{-1}$, $\mathrm{C}-\mathrm{N}$ bending appeared at $1384 \mathrm{~cm}^{-1}$, and absorption bands in the region $1000-1227 \mathrm{~cm}^{-1}$ can be due to $\mathrm{Si}-\mathrm{O}-\mathrm{Si}$ and $\mathrm{Si}-\mathrm{OH}$ [53]. FTIR spectra of the synthesized MNPs agree with those 


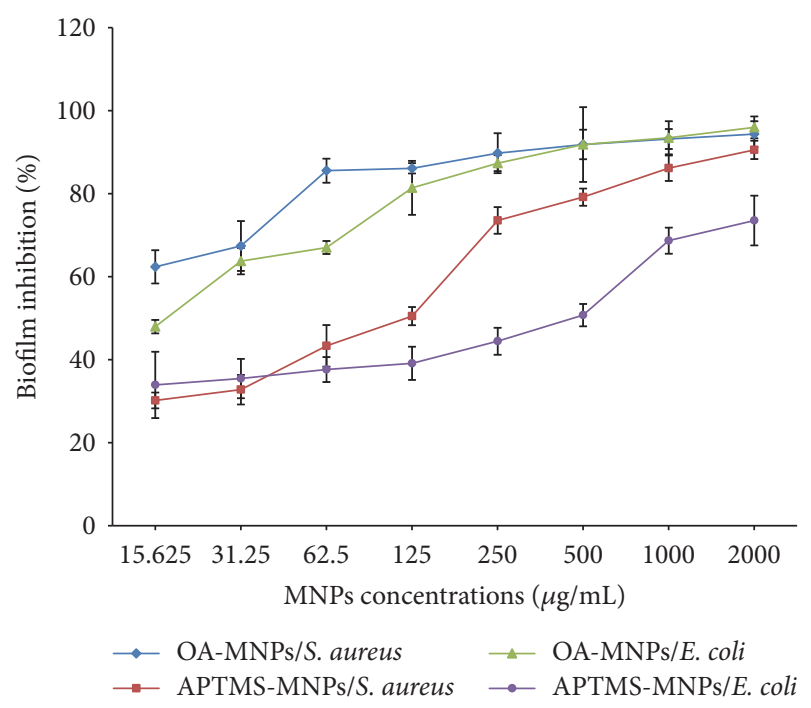

(a)

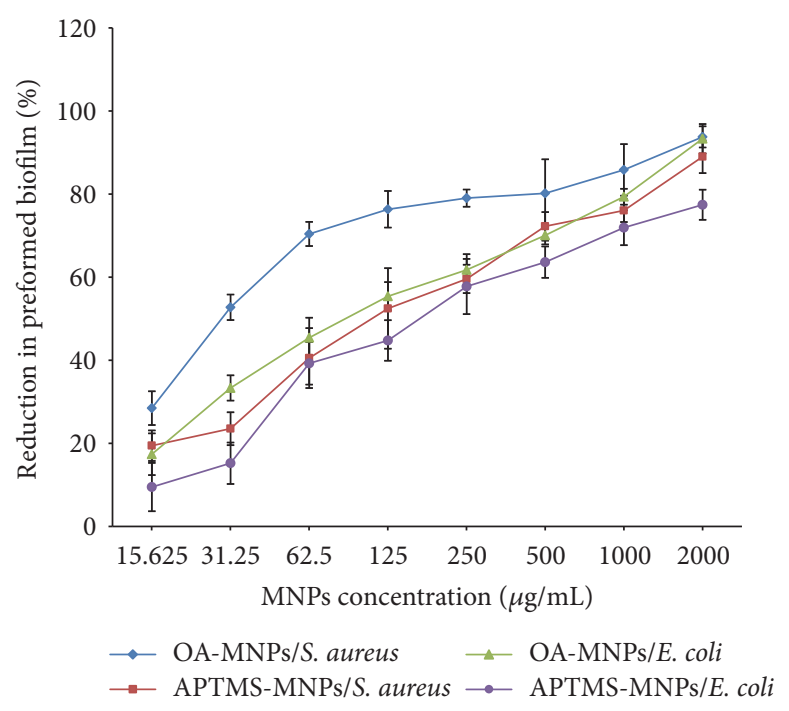

(b)

Figure 8: (a) Effect of MNPs on biofilm formation of S. aureus and E. coli after $24 \mathrm{~h}$ of growth in the presence of variable concentrations of OA-MNPs and APTMS-MNPs. Values were represented as average percentage biofilm inhibition of independent triplicates as indicated by CV assay. (b) Effects of MNPs on preformed biofilm. S. aureus and E. coli were allowed to form biofilm and then treated with different concentrations of OA-MNPs and APTMS-MNPs. Amount of the remaining biofilm was determined using crystal violet assay method of three independent tests as indicated by CV assay.

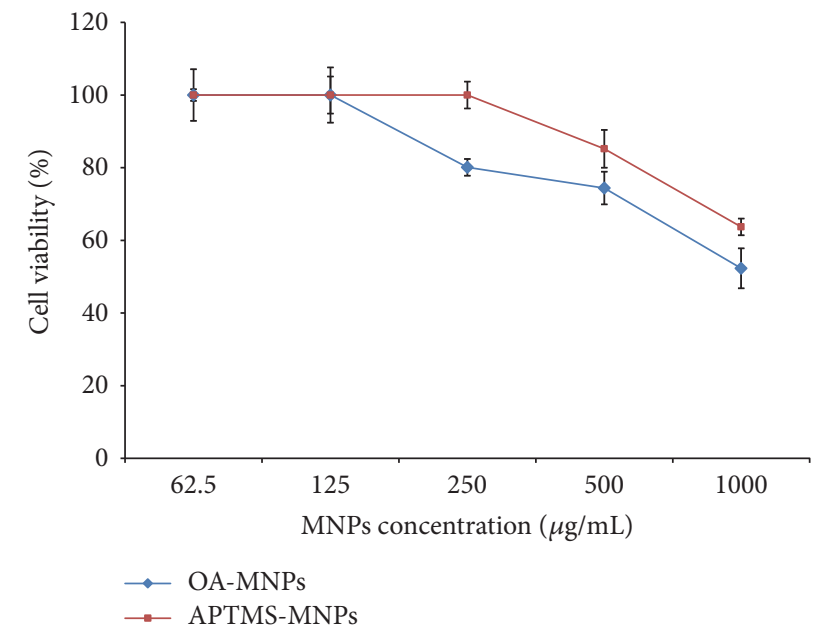

Figure 9: Cytotoxicity of OA-MNPs and APTMS-MNPs to human normal cells (WISH cells) using MTT assay $24 \mathrm{~h}$ posttreatment. The assay was based on the amount of active lactate dehydrogenase released from residual viable cells. Recorded values were the mean of independent triplicates \pm standard deviation.

obtained in previous reports indicating successful fictionalization of the prepared MNPs. A proposed mechanism of the synthesis for the six species of MNPs is shown in Figure 1.

MNPs showed insignificant antibacterial activity $[8,37$, 39]. Two physicochemical attributes were compared, namely, the surface charge and the hydrophobicity of the MNPs. This was done in the initial antibacterial screening experiment performed by counting the colony forming units. To test the effect of hydrophobicity, the effect of OA-MNPs (negatively charged hydrophobic species) was compared to that of other negatively charged hydrophilic species (MNP and CA-MNPs). The bacterial count was reduced in case of treatment with OA-MNPs, while it did not upon treatment with other negatively charged hydrophilic MNPs. Particle hydrophobicity may, therefore, play a role in facilitating the interaction between bacterial cells and MNPs.

In case of hydrophilic particles, increasing the positive charge appears to induce the antibacterial potential of particles. Hydrophilic negatively charged particles showed insignificant antibacterial activity, while modulation of surface functional group to impart a strong positive charge (e.g., ATPMS-MNPs; $24.5 \mathrm{mV}$ ) enhanced the antibacterial activity $[8,54,55]$. This indicated that surface positivity imparts antibacterial potential on the particles. Both conclusions may be justified by the fact that bacterial cells have a net negative charge on their cell wall and are relatively hydrophobic [56]. It was observed that hydrophobicity played a stronger role than charge modulation in the antibacterial potential of MNPs.

Growth kinetic analysis revealed a significant time and concentration dependent growth inhibitory potentials of both OA-MNPs and APTMS-MNPs on the tested bacterial strains.

The initial interaction of MNPs and bacteria is crucial for the NPs to exert their function as it is highly affected by surface affinity. The MNPs were mixed with bacterial suspension and were subsequently removed from the suspension by an external magnet. The number of bacterial cells per $\mathrm{mL}$ of suspension was reduced as compared to original OD. The reduction was observed directly after removing the MNPs (within $3 \mathrm{~min}$ ). This time is dramatically less than the 
duplication time of most bacteria noting that the duplication times are 15-20 min for E. coli and 27-30 min for S. aureus [57]. Thus, OD reduction is due to reduction in bacterial count due to binding of bacteria to the removed MNPs. This result supports previous reports showing strong affinity of positively charged MNPs to bacterial pathogens due to electrostatic attraction [23]. In addition, results of this study indicate that bacteria had a higher affinity to hydrophobic MNPs than hydrophilic ones. For additional confirmation, the OA-MNP was FTIR scanned before and after contacting bacteria. The difference in OA-MNP FTIR spectra represents the deposited bacteria [31-33].

Combating biofilm may be done by surface coating with a material that repels the bacterial cells preventing their attachment [58] or more effectively by inclusion of an agent which prevents biofilm formation. In the latter, the biofilm formation is reduced even in flowing system in addition to preventing its attachment to surfaces. The ability of MNPs to destroy preformed biofilm and inhibit new biofilm formation can reduce the need to use antibiotics [59]. Additionally, MNPs can simply be recovered from the medium.

Various modified NPs with antibiofilm activity such as gold NPs loaded with gentamycin [60], silver NPs surface treated with Allophylus cobbe extract [61], and copper oxide NPs [62] were reported. The effect of MNPs on preformed biofilm was previously described for OA-MNPs; however, its ability to inhibit new biofilm formation was not investigated [35]. Successful inhibition of biofilm development was reported using MNPs surface treated with polyvinylpyrrolidone and a thiourea derivative but this method included the use of an antibacterial agent [36]. Although MNPs with lactobacillus fermentation extract were also shown to have antibiofilm formation ability, it was shown to induce $E$. coli growth [55]. On the other hand, a weak effect against preformed biofilm was observed for glycerol coated MNPs [36].

In the current study, OA-MNPs (hydrophobic) and APTMS-MNPs (hydrophilic) showed a promising effect on the bacterial biofilm especially in the initial stages of biofilm development. OA-MNPs showed a stronger antibiofilm activity than the APTMS-MNPs. Our results indicated that the biofilm formed by the Gram-negative E. coli was more resistant than that formed by the Gram-positive $S$. aureus.

The electrostatic properties as well as hydrophobicity of both NPs and biofilms influence how they interact, taking in consideration that the majority of bacteria have negatively charged and hydrophobic biofilm matrixes which explains the antibiofilm ability of APTMS-MNPs and OA-MNPs [6365]. The higher suitability of $S$. aureus biofilm may be explained by its reported less negative charge than that of $E$. coli which may facilitate its interaction with the negatively charged OA-MNPs [35].

APTMS-MNP and OA-MNPs were safe to WISH cells up to 250 and $125 \mu \mathrm{g} / \mathrm{mL}$, respectively. At these concentrations, APTMS-MNPs were able to destroy preformed biofilm by $60 \%$ and $58 \%$ for S. aureus and E. coli, respectively. OAMNPs destroyed preformed biofilms by $76 \%$ and $55 \%$ for $S$. aureus and E. coli, respectively. APTMS-MNPs and OAMNPs were also able to reduce biofilm formation by $74 \%$ and
$86 \%$ for S. aureus and $44 \%$ and $81 \%$ for E. coli, respectively. Higher concentrations resulted in more effective eradication and prevention of biofilms but showed cytotoxicity which should not be a concern if MNPs are used to treat surfaces.

\section{Conclusions}

In this study, MNPs were prepared and their surface properties were successfully modified by functionalization with different chemical groups. The resulting particles had different hydrophobicity and surface charge.

Our results demonstrated that surface functional groups that induce positive charge or impart hydrophobicity could potentiate the antibacterial and antibiofilm activities of MNPs, possibly by changing the interaction at the NPs bacteria interface.

Surface modified MNPs can reduce bacterial growth. They can also reduce the ability of bacteria to form biofilms and subsequently weakens bacteria and inhibit their attachment to surfaces.

In our study, we also showed that both hydrophobic and positive charged MNPs do not only reduce the biofilm formation but also can destroy the preformed biofilms and thus crack the bacterial protecting matrix.

We demonstrated the surface affinity of hydrophobic and positively charged MNPs to bacterial cells and their ability to capture bacteria from liquid system and subsequent collection and manipulation by an external magnet. The capturing efficiency of hydrophobic positively charged MNPs can be optimized as bacterial filters or antibacterial coating materials with possibility of regeneration. OA-MNPs have a superior efficiency over APTMS-MNPs because they will not retain flowing salts or electrolytes through electrostatic interactions.

Surface modified MNPs showed promising antibiofilm potential in the safe concentration range for mammalian cells. Higher concentrations showed higher antibiofilm effects but increased cytotoxicity. This should not be a concern for applications involving treating surfaces due to the possibility of recovering MNPs using a magnet. However, it should be taken into consideration when designing MNP-based antibiofilm solutions for other applications.

From this study, we conclude that modifying MNPs surface represents a promising antibacterial and antibiofilm approach. As shown in this study, the synthesis of MNPs is easy, cheap, and a relatively simple procedure which can be performed using basic laboratory equipment. Their surface functionalization is feasible and can provide a variety of particles with adjustable physicochemical properties.

In conclusion, MNP surface properties can be tailored to fit hydrophobic and hydrophilic systems and achieve the required antibacterial and antibiofilm activity.

\section{Conflicts of Interest}

The authors declare that they have no conflicts of interest. 


\section{References}

[1] M. A. Caamano and M. Carrillo Morales, "Iron oxide nanoparticle improve the antibacterial activity of erythromycin," Journal of Bacteriology \& Parasitology, vol. 7, no. 2, 2016.

[2] A. J. Huh and Y. J. Kwon, "'Nanoantibiotics': a new paradigm for treating infectious diseases using nanomaterials in the antibiotics resistant era," Journal of Controlled Release, vol. 156, no. 2, pp. 128-145, 2011.

[3] R. A. Ismail, G. M. Sulaiman, S. A. Abdulrahman, and T. R. Marzoog, "Antibacterial activity of magnetic iron oxide nanoparticles synthesized by laser ablation in liquid," Materials Science and Engineering C, vol. 53, pp. 286-297, 2015.

[4] W. Wu, Z. Wu, T. Yu, C. Jiang, and W.-S. Kim, "Recent progress on magnetic iron oxide nanoparticles: synthesis, surface functional strategies and biomedical applications," Science and Technology of Advanced Materials, vol. 16, no. 2, Article ID 023501, 2015.

[5] M. Mahdavi, M. B. Ahmad, M. J. Haron et al., "Synthesis, surface modification and characterisation of biocompatible magnetic iron oxide nanoparticles for biomedical applications," Molecules, vol. 18, no. 7, pp. 7533-7548, 2013.

[6] A. K. Gupta and M. Gupta, "Synthesis and surface engineering of iron oxide nanoparticles for biomedical applications," Biomaterials, vol. 26, no. 18, pp. 3995-4021, 2005.

[7] P. Padwal, R. Bandyopadhyaya, and S. Mehra, "Polyacrylic acidcoated iron oxide nanoparticles for targeting drug resistance in mycobacteria," Langmuir, vol. 30, no. 50, pp. 15266-15276, 2014.

[8] M. Arakha, S. Pal, D. Samantarrai et al., "Antimicrobial activity of iron oxide nanoparticle upon modulation of nanoparticlebacteria interface," Scientific Reports, vol. 5, Article ID 14813, 2015.

[9] M. Chen, Q. Yu, and H. Sun, "Novel strategies for the prevention and treatment of biofilm related infections," International Journal of Molecular Sciences, vol. 14, no. 9, pp. 18488-18501, 2013.

[10] S. A. Crusz, R. Popat, M. T. Rybtke et al., "Bursting the bubble on bacterial biofilms: a flow cell methodology," Biofouling, vol. 28, no. 8, pp. 835-842, 2012.

[11] T. Bjarnsholt, "The role of bacterial biofilms in chronic infections," APMIS, vol. 121, no. 136, pp. 1-58, 2013.

[12] Z. L. Liu, H. B. Wang, Q. H. Lu et al., "Synthesis and characterization of ultrafine well-dispersed magnetic nanoparticles," Journal of Magnetism and Magnetic Materials, vol. 283, no. 2-3, pp. 258-262, 2004.

[13] J. P. A. J. R.-C. Fernando Herranz, "Covalent functionalization of magnetic nanoparticles for biomedical imaging," SPIE Newsroom: Biomedical Optics \& Medical Imaging, pp. 1-3, 2012.

[14] N. V. Jadhav, A. I. Prasad, A. Kumar et al., "Synthesis of oleic acid functionalized $\mathrm{Fe}_{3} \mathrm{O}_{4}$ magnetic nanoparticles and studying their interaction with tumor cells for potential hyperthermia applications," Colloids and Surfaces B: Biointerfaces, vol. 108, pp. 158-168, 2013.

[15] F. Herranz, J. Pellico, and J. Ruiz-Cabello, "Covalent functionalization of magnetic nanoparticles for biomedical imaging," SPIE Newsroom, vol. 4, no. 6, 2012.

[16] Z. Chen, W. Xu, L. Jin et al., "Synthesis of amine-functionalized $\mathrm{Fe}_{3} \mathrm{O}_{4} @ \mathrm{C}$ nanoparticles for lipase immobilization," Journal of Materials Chemistry A, vol. 2, no. 43, pp. 18339-18344, 2014.

[17] M. E. de Sousa, M. B. Fernández Van Raap, P. C. Rivas et al., "Stability and relaxation mechanisms of citric acid coated magnetite nanoparticles for magnetic hyperthermia," The Journal of Physical Chemistry C, vol. 117, no. 10, pp. 5436-5445, 2013.
[18] D. Singh, R. K. Gautam, R. Kumar, B. K. Shukla, V. Shankar, and V. Krishna, "Citric acid coated magnetic nanoparticles: synthesis, characterization and application in removal of Cd(II) ions from aqueous solution," Journal of Water Process Engineering, vol. 4, pp. 233-241, 2014.

[19] S. P. Schwaminger, P. F. García, G. K. Merck et al., "Nature of interactions of amino acids with bare magnetite nanoparticles," The Journal of Physical Chemistry C, vol. 119, no. 40, pp. 2303223041, 2015.

[20] M. Raffi, F. Hussain, T. M. Bhatti, J. I. Akhter, A. Hameed, and M. M. Hasan, "Antibacterial characterization of silver nanoparticles against E. coli ATCC-15224," Journal of Materials Science and Technology, vol. 24, no. 2, pp. 192-196, 2008.

[21] N. Jones, B. Ray, K. T. Ranjit, and A. C. Manna, "Antibacterial activity of $\mathrm{ZnO}$ nanoparticle suspensions on a broad spectrum of microorganisms," FEMS Microbiology Letters, vol. 279, no. 1, pp. 71-76, 2008.

[22] M. K. Sachidananda, S. K. Murari, and D. Channe Gowda, "Characterization of an antibacterial peptide from Indian cobra (Naja naja) venom," Journal of Venomous Animals and Toxins Including Tropical Diseases, vol. 13, no. 2, pp. 446-461, 2007.

[23] Y.-F. Huang, Y.-F. Wang, and X.-P. Yan, “Amine-functionalized magnetic nanoparticles for rapid capture and removal of bacterial pathogens," Environmental Science and Technology, vol. 44, no. 20, pp. 7908-7913, 2010.

[24] R. Davis and L. J. Mauer, "Fourier transform infrared (FT-IR) spectroscopy: a rapid tool for detection and analysis of foodborne pathogenic bacteria," in Current Research, Technology and Education Topics in Applied Microbiology and Microbial Biotechnology, vol. 2, pp. 1582-1594, 2010.

[25] C. Haney, J. Rowe, and J. Robinson, "Spions increase biofilm formation by Pseudomonas aeruginosa," Journal of Biomaterials and Nanobiotechnology, vol. 3, pp. 508-518, 2012.

[26] E. El-Gebaly, T. Essam, S. Hashem, and R. A. El-Baky, "Effect of levofloxacin and vitamin $\mathrm{C}$ on bacterial adherence and preformed biofilm on urethral catheter surfaces," Journal of Microbial and Biochemical Technology, vol. 4, no. 6, pp. 131-136, 2012.

[27] S. Vijayakumar and S. Ganesan, "In vitro cytotoxicity assay on gold nanoparticles with different stabilizing agents," Journal of Nanomaterials, vol. 2012, Article ID 734398, 9 pages, 2012.

[28] R. Mannhold, H. Kubinyi, H. Timmerman, V. Pliska, B. Testa, and H. van de Waterbeemd, Lipophilicity in Drug Action and Toxicology, John Wiley \& Sons, Hoboken, NJ, USA, 2008.

[29] Minerals Arranged by X-Ray Powder Diffraction, http://webmineral.com/MySQL/xray.php?lambda=1.54056+-+CuKal\&lambdal= \&ed1 $=1.61 \&$ ed $2=2.957 \&$ ed $3=2.53 \& \operatorname{minmax}=2 \&$ chem $=\&$ submit $=$ Submit\#.WYV5GWjvuM9.

[30] K. Song, S. Lee, C.-Y. Suh, W. Kim, K.-S. Ko, and D. Shin, "Synthesis and characterization of iron oxide nanoparticles prepared by electrical explosion of fe wire in $\mathrm{Ar}^{-} \mathrm{O}_{2}$ gas mixtures," Materials Transactions, vol. 53, no. 11, pp. 2056-2059, 2012.

[31] V. Prabhawathi, T. Boobalan, P. M. Sivakumar, and M. Doble, "Functionalized polycaprolactam as an active food package for antibiofilm activity and extended shelf life," Colloids and Surfaces B: Biointerfaces, vol. 123, pp. 461-468, 2014.

[32] E. R. Cordeiro, A. W. C. Fernandes, A. F. C. Pereira, M. M. Da Costa, M. L. F. Nascimento, and H. P. De Oliveira, "Staphylococcus aureus biofilm formation on polypyrrole: an electrical overview," Química Nova, vol. 38, no. 8, pp. 1075-1079, 2015. 
[33] J.-W. Liou, Y.-J. Hung, C.-H. Yang, and Y.-C. Chen, “The antimicrobial activity of gramicidin a is associated with hydroxyl radical formation," PLoS ONE, vol. 10, no. 1, Article ID 0117065, 2015.

[34] T. Naseem and M. A. Farrukh, "Antibacterial activity of green synthesis of iron nanoparticles using lawsonia inermis and gardenia jasminoides leaves extract," Journal of Chemistry, vol. 2015, Article ID 912342, 7 pages, 2015.

[35] P. Velusamy, S. Chia-Hung, A. Shritama, G. V. Kumar, V. Jeyanthi, and K. Pandian, "Synthesis of oleic acid coated iron oxide nanoparticles and its role in anti-biofilm activity against clinical isolates of bacterial pathogens," Journal of the Taiwan Institute of Chemical Engineers, vol. 59, pp. 450-456, 2016.

[36] S. L. Iconaru, A. M. Prodan, P. Le Coustumer, and D. Predoi, "Synthesis and antibacterial and antibiofilm activity of iron oxide glycerol nanoparticles obtained by coprecipitation method," Journal of Chemistry, vol. 2013, Article ID 412079, 6 pages, 2013.

[37] S. Arokiyaraj, M. Saravanan, N. K. Udaya Prakash, M. Valan Arasu, B. Vijayakumar, and S. Vincent, "Enhanced antibacterial activity of iron oxide magnetic nanoparticles treated with Argemone mexicana L. leaf extract: an in vitro study," Materials Research Bulletin, vol. 48, no. 9, pp. 3323-3327, 2013.

[38] Y. Haldorai, D. Kharismadewi, D. Tuma, and J.-J. Shim, "Properties of chitosan/magnetite nanoparticles composites for efficient dye adsorption and antibacterial agent," Korean Journal of Chemical Engineering, vol. 32, no. 8, pp. 1688-1693, 2015.

[39] G. Subbiahdoss, S. Sharifi, D. W. Grijpma et al., "Magnetic targeting of surface-modified superparamagnetic iron oxide nanoparticles yields antibacterial efficacy against biofilms of gentamicin-resistant staphylococci," Acta Biomaterialia, vol. 8, no. 6, pp. 2047-2055, 2012.

[40] S. H. Hussein-Al-Ali, M. E. El Zowalaty, M. Z. Hussein, M. Ismail, and T. J. Webster, "Synthesis, characterization, controlled release, and antibacterial studies of a novel streptomycin chitosan magnetic nanoantibiotic," International Journal of Nanomedicine, vol. 9, no. 1, pp. 549-557, 2014.

[41] S. H. Hussein-Al-Ali, M. E. El Zowalaty, M. Z. Hussein, B. M. Geilich, and T. J. Webster, "Synthesis, characterization, and antimicrobial activity of an ampicillin-conjugated magnetic nanoantibiotic for medical applications," International Journal of Nanomedicine, vol. 9, no. 1, pp. 3801-3814, 2014.

[42] N. Tran, A. Mir, D. Mallik, A. Sinha, S. Nayar, and T. J. Webster, "Bactericidal effect of iron oxide nanoparticles on Staphylococcus aureus," International Journal of Nanomedicine, vol. 5, no. 1, pp. 277-283, 2010.

[43] P. Padwal, R. Bandyopadhyaya, and S. Mehra, "Biocompatible citric acid-coated iron oxide nanoparticles to enhance the activity of first-line anti-TB drugs in Mycobacterium smegmatis," Journal of Chemical Technology and Biotechnology, vol. 90, no. 10, pp. 1773-1781, 2015.

[44] M. Bloemen, W. Brullot, T. T. Luong, N. Geukens, A. Gils, and T. Verbiest, "Improved functionalization of oleic acid-coated iron oxide nanoparticles for biomedical applications," Journal of Nanoparticle Research, vol. 14, no. 9, article 1100, 2012.

[45] D. Rehana, A. K. Haleel, and A. K. Rahiman, "Hydroxy, carboxylic and amino acid functionalized superparamagnetic iron oxide nanoparticles: synthesis, characterization and in vitro anti-cancer studies," Journal of Chemical Sciences, vol. 127, no. 7, pp. 1155-1166, 2015.

[46] Q. Wu, N. Meng, Y. Zhang et al., “The effect of two novel amino acid-coated magnetic nanoparticles on survival in vascular endothelial cells, bone marrow stromal cells, and macrophages," Nanoscale Research Letters, vol. 9, no. 1, article 461, 2014.

[47] K.-M. Kim, H. M. Kim, W.-J. Lee et al., "Surface treatment of silica nanoparticles for stable and charge-controlled colloidal silica," International Journal of Nanomedicine, vol. 9, pp. 29-40, 2014.

[48] R. A. Bini, R. F. C. Marques, F. J. Santos, J. A. Chaker, and M. Jafelicci Jr., "Synthesis and functionalization of magnetite nanoparticles with different amino-functional alkoxysilanes," Journal of Magnetism and Magnetic Materials, vol. 324, no. 4, pp. 534-539, 2012.

[49] Z. Shan, W.-S. Yang, X. Zhang, Q.-M. Huang, and H. Ye, "Preparation and characterization of carboxyl-group functionalized superparamagnetic nanoparticles and the potential for bioapplications," Journal of the Brazilian Chemical Society, vol. 18, no. 7, pp. 1329-1335, 2007.

[50] R. A. Harris, P. M. Shumbula, and H. Van Der Walt, "Analysis of the interaction of surfactants oleic acid and oleylamine with iron oxide nanoparticles through molecular mechanics modeling," Langmuir, vol. 31, no. 13, pp. 3934-3943, 2015.

[51] A. Hardiansyah, L.-Y. Huang, M.-C. Yang et al., "Magnetic liposomes for colorectal cancer cells therapy by high-frequency magnetic field treatment," Nanoscale Research Letters, vol. 9, no. 1, pp. 1-13, 2014.

[52] A. Ebrahiminezhad, Y. Ghasemi, S. Rasoul-Amini, J. Barar, and S. Davaran, "Preparation of novel magnetic fluorescent nanoparticles using amino acids," Colloids and Surfaces B: Biointerfaces, vol. 102, pp. 534-539, 2013.

[53] B. Sahoo, S. Dutta, and D. Dhara, "Amine-functionalized magnetic nanoparticles as robust support for immobilization of Lipase," Journal of Chemical Sciences, vol. 128, no. 7, pp. 11311140, 2016.

[54] B. Stephen Inbaraj, T.-Y. Tsai, and B.-H. Chen, "Synthesis, characterization and antibacterial activity of superparamagnetic nanoparticles modified with glycol chitosan," Science and Technology of Advanced Materials, vol. 13, no. 1, Article ID 015002, 2012.

[55] J. A. S. Salman, M. F. A. Marjani, R. A. Abdulrazaq, I. A. S. S. Kamil, and N. B. Kamil, "Antibiofilm effect of iron oxide nanoparticles synthesized by lactobacillus fermentum on catheter," World Journal of Pharmaceutical Research, vol. 4, no. 8, 2015.

[56] J. S. Dickson and M. Koohmaraie, "Cell surface charge characteristics and their relationship to bacterial attachment to meat surfaces," Applied and Environmental Microbiology, vol. 55, no. 4, pp. 832-836, 1989.

[57] Todar's Online book of bacteriology, http://textbookofbacteriology .net/growth_3.html.

[58] G. Feng, Y. Cheng, S. Wang, D. A. Borca-Tasciuc, R. W. Worobo, and C. I. Moraru, "Bacterial attachment and biofilm formation on surfaces are reduced by small-diameter nanoscale pores: how small is small enough?" npj Biofilms and Microbiomes, vol. 1, no. 1, article 15022, 2015.

[59] M. Mahmoudi and V. Serpooshan, "Silver-coated engineered magnetic nanoparticles are promising for the success in the fight against antibacterial resistance threat," ACS Nano, vol. 6, no. 3, pp. 2656-2664, 2012.

[60] H. Mu, J. Tang, Q. Liu, C. Sun, T. Wang, and J. Duan, "Potent antibacterial nanoparticles against biofilm and intracellular bacteria," Scientific Reports, vol. 6, Article ID 18877, 2016.

[61] S. Gurunathan, J. W. Han, D.-N. Kwon, and J.-H. Kim, "Enhanced antibacterial and anti-biofilm activities of silver 
nanoparticles against Gram-negative and Gram-positive bacteria," Nanoscale Research Letters, vol. 9, no. 1, pp. 1-17, 2014.

[62] M. Agarwala, B. Choudhury, and R. N. S. Yadav, "Comparative study of antibiofilm activity of copper oxide and iron oxide nanoparticles against multidrug resistant biofilm forming uropathogens," Indian Journal of Microbiology, vol. 54, no. 3, pp. 365-368, 2014.

[63] A. Pagedar, J. Singh, and V. K. Batish, "Surface hydrophobicity, nutritional contents affect Staphylococcus aureus biofilms and temperature influences its survival in preformed biofilms," Journal of Basic Microbiology, vol. 50, supplement 1, pp. S98S106, 2010.

[64] A. Krasowska and K. Sigler, "How microorganisms use hydrophobicity and what does this mean for human needs?" Frontiers in Cellular and Infection Microbiology, vol. 4, article 112, 2014.

[65] M. J. Hajipour, K. M. Fromm, A. Akbar Ashkarran et al., "Antibacterial properties of nanoparticles," Trends in Biotechnology, vol. 30, no. 10, pp. 499-511, 2012. 

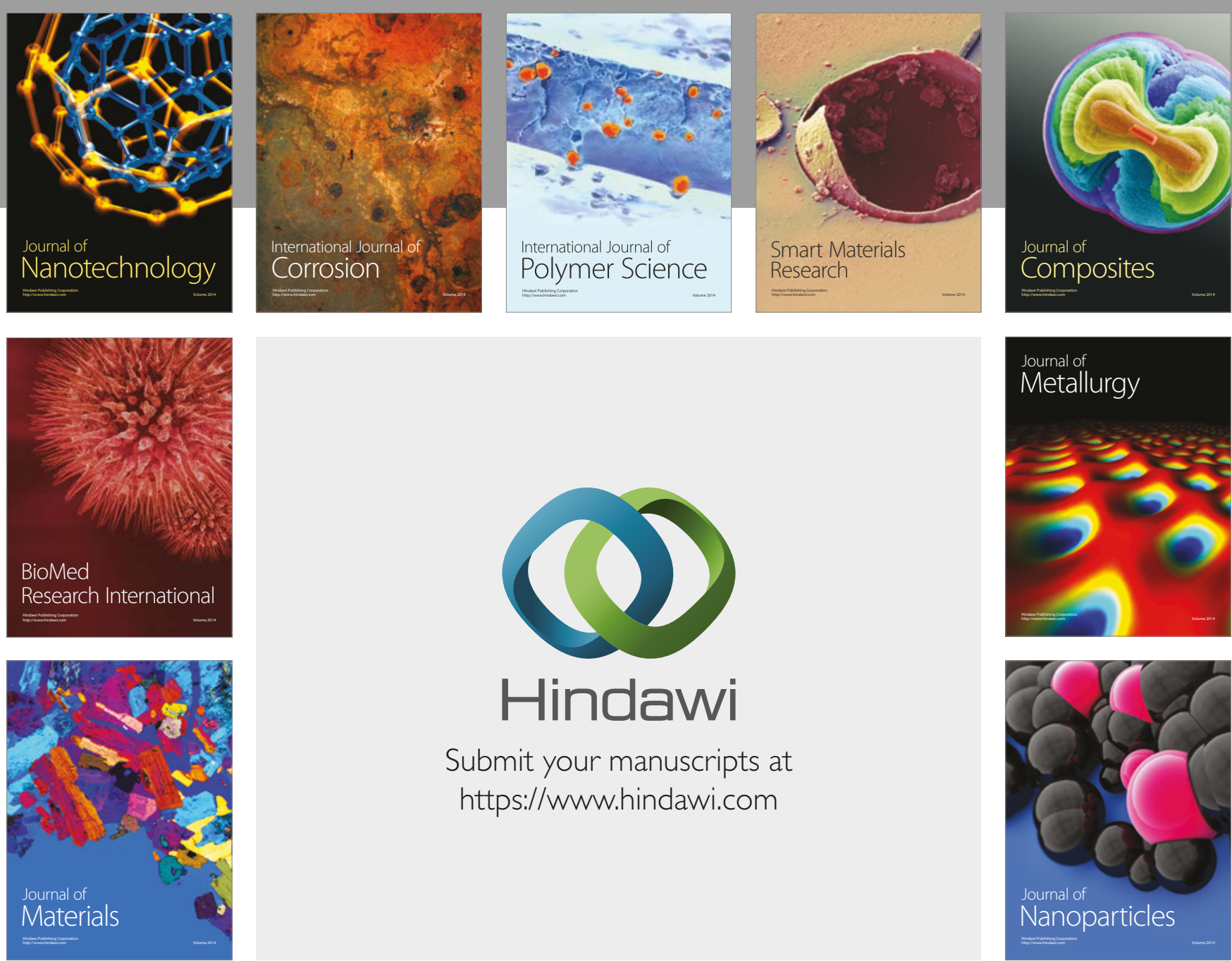

\section{Hindawi}

Submit your manuscripts at

https://www.hindawi.com
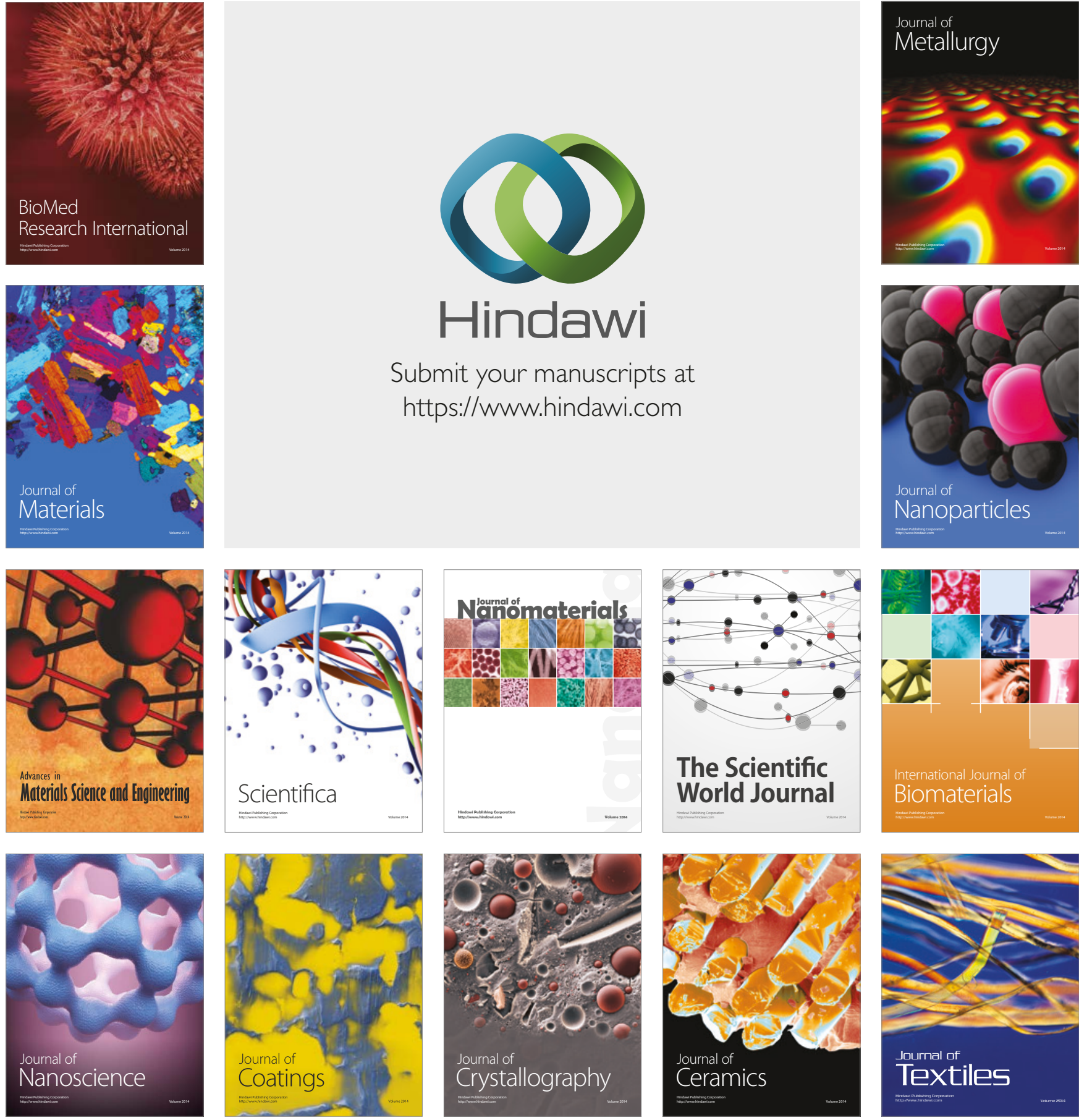

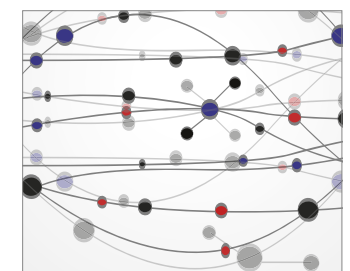

The Scientific World Journal
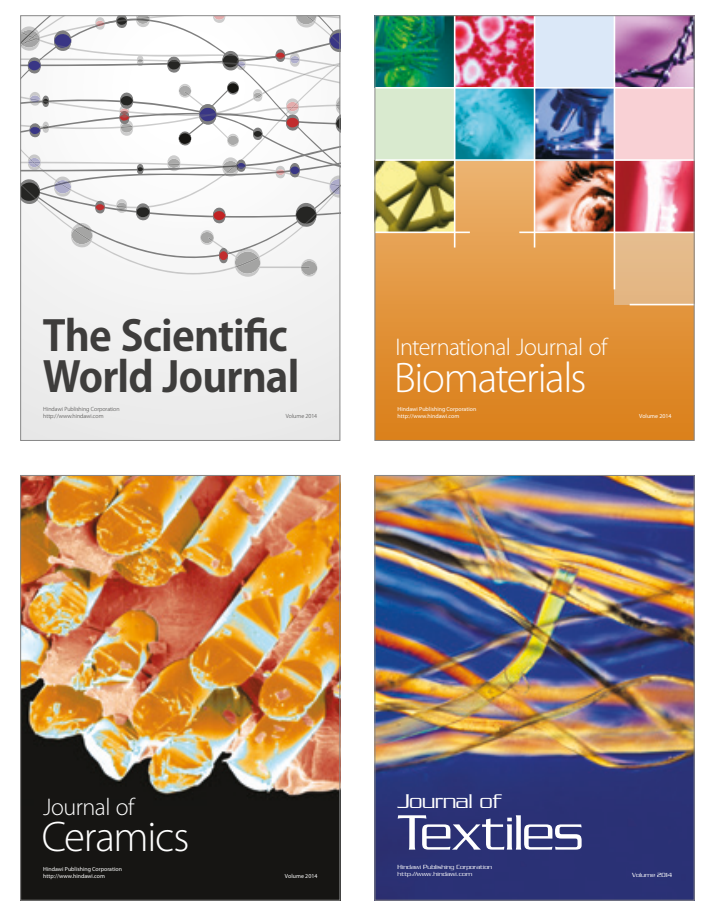